\title{
NAPOLI-SIGNORELLI Y EL TEATRO ÁUREO EN EL XVIII: LA CRÍTICA A LAS TRAGEDIAS DE CALDERÓN
}

\author{
Franco Quinziano \\ Universidad de Estudios Extranjeros de Kyoto
}

\begin{abstract}
The present article is an attemp to examine the commentaries that the hispanist Napoli Signorelli dedicated to the tragic aspects of Calderon's work, and remained on his monumental work Storia critica dei teatri antichi e moderni. The italian author -fervent follower of the Neoclassic Theatre, friend of Nicolás Moratín and translator of the comedies of his son, the famous dramatist Leandro- in these pages considers favourably some scenes, above all the "querellas patéticas", as well as some characters, specially the feminines (Mariene, Dorotea, Semíramis). Nevertheless, following the classicism canons, the napolitan critic perceives that Calderon's tragedies suffers from numerous irregularities and therefore doubts about his talent as tragic author. On the contrary, he argues that Calderón's genius was more prone to the comic universe, as reveals him the comedies "de capa y espada".
\end{abstract}

\section{NAPOLI SignORELLI: CRÍTICO TEATRAL EN LA ESPAÑA DE CARLOS III}

Pedro Napoli Signorelli constituye sin duda una de las figuras más significativas en el amplio entramado de las relaciones culturales y literarias que España e Italia entablaron a lo largo de la segunda mitad del siglo XVIII. No es ocioso recordar que la intensa actividad literaria que caracteriza el Madrid de mediados de los años sesenta del XVIII favoreció la rápida inserción del hispanista napolitano en la vida cultural de la capital. Es bien conocida la favorable acogida, "piena di simpatia" (Bigi 1960: 590), tanto en los ámbitos cercanos a la Corte como en los más prestigiosos círculos culturales que ofrecía el Madrid de Carlos III y que, una vez afincado nuevamente en su Nápoles natal, dejó en el ánimo del literato italiano una grata nostalgia de los años transcurridos en la península ibérica ${ }^{1}$. De las copiosas amistades cultivadas en aquellos años, de la favorable acogida que tuvo a su llegada en España y de las innumerables manifestaciones de estima y afecto que el napolitano recibió en Madrid dan cuenta su epistolario ${ }^{2}$ y los numerosos comentarios que

\footnotetext{
${ }^{1}$. Sobre la estancia madrileña, de casi cuatro lustros, del crítico partenopeo, remito a mi estudio (Quinziano, 2003: 241-264).

${ }^{2}$. Mininni (1914) recoge más de ciento sesenta cartas del napolitano, aunque hay que lamentar el hecho de que gran parte del nutrido epistolario de Signorelli de aquellos años, referido al período madrileño, como recuerda el mismo literato, se haya extraviado después de su definitivo regreso a Nápoles en 1783. El italiano lamenta la pérdida de su carteggio "per tanti anni continuato coi suoi più cari virtuosi amici", debido sobre todo a "l'incuria dei miei che trascurarono di custodir quelle carte, stimandole da me abbandonate" (Opuscoli Varii, I: 10), privándonos así de mayores detalles y de información valiosa sobre su larga experiencia madrileña.
} 
salpican algunos de sus textos, de modo especial su monumental Storia critica de' teatri antichi e moderni (1777), redactada, como el mismo autor nos confiesa, en primera instancia en español. En sus largos años en Madrid, que se prolongó por casi dos décadas, de setiembre de 1765 a finales de 1783, el escritor napolitano perfeccionaría el estudio del castellano, idioma, según sus propias palabras, "rico, expresivo, majestuoso, (...) armonioso y noble" (SCT, VII: 3-4), que llegó a dominar con pericia filológica, ampliando al mismo tiempo sus estudios hispánicos, con particular atención al género dramático y a los autores del teatro áureo.

La febril actividad cultural que se respira en los años sesenta de la centuria le dan la oportunidad, asimismo, de estrechar nuevas y decisivas relaciones personales y literarias, favoreciendo de este modo su rápida inserción en los círculos y en los ámbitos de debate y de producción cultural más prestigiosos de aquellos años. El autor partenopeo, en efecto, logra establecer en Madrid una vasta red de contactos personales y literarios, en el que destaca el importante vínculo de amistad que estrechó con diversos intelectuales y escritores pertenecientes al círculo cultural aglutinado en torno a Nicolás Fernández de Moratín, con quien el crítico italiano habría de cultivar una intensa relación de amistad, proseguida, después de la prematura muerte del dramaturgo madrileño, y hasta sus últimos días, con su hijo, el célebre comediógrafo Leandro ${ }^{3}$. Si, como hemos apuntado, con Nicolás Moratín el italiano "mantuvo una fructífera relación de carácter personal y literaria, dando lugar a un vínculo ejemplar que aunó experiencia de vida y afinidades literarias" (Quinziano, 2003: 254), no cabe duda alguna que su hijo Leandro representó "un punto de referencia insustituible en el mundo de contactos y de amistades personales que el napolitano había logrado establecer a lo largo de su vida; una amistad de ningún modo secundaria o accidental que el mismo literato italiano en reiteradas ocasiones se encargó de reivindicar y de exaltar públicamente" (Quinziano 2002: 230-1).

La importante relación que el autor partenopeo estrechó con ambos dramaturgos marcará su rumbo literario y estético, incidiendo de modo crucial en sus preferencias literarias y estéticas, de modo evidente por lo que respecta a sus ideas dramáticas y a su visión y concepción del teatro español, tanto por lo que atañe al drama áureo como a la producción teatral del setecientos. Casi todos los biógrafos han resaltado la importancia de esta doble relación, recordando cómo, gracias a las gestiones de su amigo Nicolás Moratín, Napoli Signorelli había logrado entrar en contacto con los ambientes culturales y los círculos ilustrados madrileños más avanzados. Es en estos encuentros, en los que, entre otros, participan sus amigos italianos Bernascone y Giambattista Conti, y en los que el teatro y los modelos clasicistas constituyen temas de debate privilegiados, animando las veladas de los contertulios que frecuentan la fonda de San Sebastián, que el autor napolitano va madurando y delimitando los ejes de su pensamiento y al mismo tiempo afirmando gustos y preferencias literarias. Su inserción en el afamado cenáculo madrileño, constituyeron al mismo tiempo una valiosa ocasión para ampliar sus conocimientos sobre la cultura española, en particular sobre el teatro peninsular, al tiempo que le procuró nuevas e importantes relaciones, tanto sociales como culturales.

\footnotetext{
${ }^{3}$ Sobre la relación que el italiano entabló con los dos Moratines, véanse Mariutti Sánchez de Rivero (1960: 763808) y mis recientes estudios: Quinziano (2001: 265-9; 2002: 199-231 y 2003: 253-5).
} 
De su doble actividad de crítico teatral y traductor de textos españoles dan cuenta tanto las amplias páginas dedicadas al drama hispánico que pueden leerse en su Storia critica dei teatri, uno de los primeros intentos orientados a trazar una historia general del género dramático dentro de la vastidad de lo que en el XVIII se entendía por 'literatura', como sus apreciables traducciones de las comedias de Leandro Moratín, dejando constancia así de la plena adhesión que el erudito partenopeo guardó hacia los principios estéticos que guiaron la visión dramática del amigo madrileño. Napoli Signorelli, hombre de teatro en el sentido más amplio del término (crítico, dramaturgo, traductor e historiador dramático, sin olvidar su temprana experiencia como actor en los escenarios napolitanos), fue modelando su percepción del hecho dramático precisamente en aquellos años en Madrid, a caballo entre los siglos sesenta y setenta, privilegiando un modelo artístico que resaltaba la función social y didáctica del teatro. En España el escritor abrazó en modo incondicional la nueva estética clasicista, cuyos contenidos en el ámbito teatral se propuso desarrollar y defender en dos obras de preceptiva y crítica, ambas complementarias entre sí, Elementi di poesia drammatica (EP) y Ragionamento sul gusto e sul bello, las cuales vieron la luz en los primerísimos años del XIX. En estos dos textos el crítico partenopeo traza su visión sobre el tan debatido tema del 'gusto' y sobre los contenidos y la naturaleza de la poesía dramática, acogiéndose a los preceptos que aconsejan el respeto de las 'reglas del arte', el buen gusto y el decoro en los escenarios. Se percibe en ambos textos el influjo de los italianos, de modo especial Gravina, Cresciembeni, Muratori y Cesarotti. Del mismo modo no hay que olvidar que en numerosos pasajes el crítico napolitano apoya sus comentarios siguiendo las indicaciones de Ludovico Castelvetro (Poetica d'Aristotele volgarizzata et sposta, Viena, 1570) y que Napoli Signorelli acogió como propias en su estudio sobre el género trágico, mientras que en su Storia critica dei Teatri abundan las referencias a la Poética luzaniana, como autoridad respetable, de la que echa mano para validar los juicios allí vertidos, sobre todo cuando se ocupa del drama hispánico.

Estimable ha sido la labor por él desempeñada como crítico teatral e historiador de la cultura, como se desprende de las dos obras de mayor alcance que el italiano nos ha legado, la Storia crítica dei teatri, y las Vicende della cultura delle due Sicilie (1784-86), redactadas ambas en su mayor parte durante su estancia madrileña. En dicha perspectiva no es azaroso concebir al literato partenopeo como uno de los mejores conocedores de la vida teatral de su tiempo, no sólo de la italiana, sino también de la española y europea en general, como se desprende de las pertinentes consideraciones y de la vastedad de datos que informan su obra de mayor alcance, la recién aludida Storia crítica de' teatri, fruto por lo general de amplias lecturas y de un conocimiento directo de las fuentes, algo no muy común en aquellos decenios. Con Cian (1896: 184), somos de la opinión de que en este valorable esfuerzo historiográfico, por supuesto no exento de errores y de algunas llamativas ausencias e interpretaciones no siempre afortunadas -fruto, por lo general, de su estricta adhesión a los principios neoclásicos y de su vena polémica-, los tres amplios capítulos dedicados al teatro español ${ }^{4}$ constituyen con toda probabilidad sus páginas más interesantes, revelando sin duda dichos apartados una parcela obligada en el complejo

\footnotetext{
${ }^{4}$ Véanse los amplios capítulos que le dedica al teatro español en su obra monumental: SCT VI: 137-226 (siglos XV y XVI); VII: 3-134 (siglo XVII y principios del XVIII) y IX: 56-194 (siglo XVIII).
} 
entramado de influjos, afinidades estéticas, traducciones, preceptivas y recepción que han configurado la dramaturgia comparada de los períodos en cuestión.

\section{NAPOLI SigNORELLI Y LA CRÍTICA NEOCLÁSICA A CALDERÓN}

Durante sus primeros años en la ciudad española el literato napolitano fue asimilando las nuevas ideas estéticas y teatrales, solidarizándose tempranamente con la corriente neoclásica que se aglutinaba en torno a Moratín padre. Su hijo Leandro Moratín recordaba que había sido aquél quien había incitado al escritor italiano a que estudiara y conociese de modo apropiado, libre de todo prejuicio, los autores del teatro áureo español, instruyéndolo sobre sus cualidades y virtudes ${ }^{5}$ (1944: XIV). Importante además para un mayor conocimiento de los obras de los grandes autores del siglo de oro fue sin duda la bien provista biblioteca que le acercó su amigo madrileño. Como evocaba el autor de El Sí de las niñas, su padre "puso en manos de aquel docto escritor [italiano] cuanto halló de más apreciable en este género" (1944: IX). A ello es posible añadir las bibliotecas privadas y públicas de la corte, las cuales le ofrecieron a Signorelli la posibilidad de entrar en contacto directo con no pocas fuentes valiosas y con numerosos textos de nuestro teatro clásico. Todo ello sin olvidar por supuesto su valiosa experiencia como espectador durante sus años en Madrid, al poder asistir a numerosas representaciones en los coliseos de la ciudad, lo que le permitió además verificar y confrontar las fuentes estudiadas con las puestas en escena y las adaptaciones dieciochescas y cuyos comentarios vertebran los sustanciosos capítulos que dedicó al drama hispánico en su Historia crítica de los Teatros.

Para comprender las preferencias del autor italiano en campo teatral y de modo especial su visión acerca del drama español, no debe olvidarse que su llegada a Madrid había coincidido con uno de los momentos más intensos en la batalla que los neoclásicos libraban por desterrar de los escenarios los epígonos del modelo teatral que había imperado a lo largo de la centuria precedente ${ }^{6}$. Como se sabe, los neoclásicos identificaron en los continuadores del gusto que habían popularizado las comedias áureas a sus principales adversarios, puesto que advertían en ellas, y en el modelo sobre la que éstas se habían gestado, la principal causa de la 'corrupción' por el que atravesaban los escenarios nacionales. Napoli Signorelli apoyó esta ofensiva de los partidarios del neoclasicismo en pos de un teatro burgués de rango europeo, difusor de modelos ético-morales en la sociedad y encaminado a la educación de los ciudadanos y volcó sus energías en dicha dirección. Asimismo, como he precisado en otro estudio, "la batalla por la reforma de los escenarios

\footnotetext{
${ }^{5}$ El popular comediógrafo escribe que "ocupábase por entonces Signorelli en escribir la Historia crítica de los teatros; y [Nicolás] Moratín, que cuando habló á sus compatiotras fue el más rígido censor de los defectos del nuestro, no quería que Signorelli ignorase los rasgos de ingenio felicísimos, las situaciones patéticas y cómicas, ni el mérito de lenguaje, facilidad y armonía que se encuentra en los desarreglados dramas de Lope, Calderón, Moreto, Rojas, Salazar, Solís y otros de su tiempo (...)” (L. Moratín, 1944: XIV).

${ }^{6}$ Su arribo a Madrid en el mes de septiembre de 1765, en efecto, coincide con uno de los momentos más álgidos en la enconada batalla que los defensores del neoclasicismo llevaban adelante por afirmar un nuevo modelo dramático, puesto que, como el mismo literato italiano nos recuerda (SCT: VII: 57), tan sólo algunos meses antes, en junio, Carlos III había prohibido los autos sacramentales y había renovado la interdicción de las comedias de santos y otras de temas sacro, decretando con ello el primer triunfo de los partidarios del clasicismo. Del mismo modo, a los pocos meses de su arribo a la capital del reino, y a raíz de los sucesos de Aranjuez, asumía la presidencia del Consejo el conde de Aranda, promotor en los años sucesivos de una serie de iniciativas tendientes a reformar, en clave clasicista, los escenarios nacionales y que el napolitano apoyó con entusiasmo.
} 
fue afianzando en nuestro autor el carácter colectivo de la amistad y al mismo tiempo (...) un sentido de pertenencia cultural bien preciso, de plena identificación con el círculo reformista ilustrado" (Quinziano, 2003: 253). La propagación de las 'reglas del arte' y del 'buen gusto', como es notorio, comportó el rechazo del modelo teatral que había dominado durante la centuria anterior, de modo particular las comedias áureas, las cuales, gracias a los continuadores del modelo de Lope y Calderón, siguieron gozando de cierta consideración y del favor del público hasta bien entrado el setecientos. Ante las profundas transformaciones políticas y culturales que habían signado el cambio de dinastía en los albores del siglo, y al enfrentarse -y confrontarse- una vez más con las coordenadas culturales sobre las que iba configurándose la cultura europea moderna, dominada por el pensamiento cartesiano de lo claro, equilibrado y racional, España fue modificando sus códigos tanto lingüísticos como ideológicos. En dicha perspectiva, los dramaturgos áureos fueron objeto de una continuada y encendida polémica a lo largo de toda la centuria y en esta nutrida literatura crítica a la que se abocaron autores y polemistas durante el XVIII, Lope y Calderón han llevado la parte del león: si "a Calderón se le solía achacar (...) frecuentes inverosimilitudes, a Lope se le reprochaba (...) sus faltas a la inverosimilitud, al decoro y a la propiedad de la fábula dramática" (Checa Beltrán 1990: 30). Por lo que se refiere al estilo de la lengua se les criticó por su 'hinchada afectación' y por su estilo hiperbólico, de modo particular a Calderón, reprochándoseles el uso frecuente de metáforas atrevidas, en gran medida derivadas de la poesía gongorina ${ }^{7}$.

La crítica en el setecientos revela la urgencia por determinar las bases éticas y estéticas sobre las que erigir un nuevo modelo teatral (Checa Beltrán, 1990: 13-31). Siendo el napolitano, convencido partidario de los dogmas neoclásicos, no cabe duda de que sus comentarios sobre el teatro áureo se hallan fuertemente condicionados por dicha perspectiva. Al teatro aurisecular Signorelli dedicó nutridas páginas, dividiendo su estudio en dos amplios capítulos, desde los orígenes hasta finales del XVI y desde principios del XVII a inicios de la siguiente centuria. El autor reivindicará estas páginas como las primeras encaminadas, en una perspectiva histórica general, al análisis de todo el teatro español, concibiendo por tanto a las mismas como precursoras en el campo de la historiografía del teatro ${ }^{8}$. En su apartado sobre el drama áureo, el hispanista italiano dedicó amplio espacio a Calderón y a los continuadores de su escuela dramática, de modo especial a Moreto, Solís y Bances Candamo. El autor partenopeo resalta la vigencia y la popularidad de las obras del gran comediógrafo español, precisando que muchas de sus comedias, al igual que las lopianas, siguen gozando del favor del público allende los Pirineos ${ }^{9}$. De modo

\footnotetext{
${ }^{7}$ A este respecto Napoli Signorelli recordaba que "il giudizioso Luzán" ya se había ocupado de ambos dramaturgos, orientando sus reproches a los que él define "spropositati groppi gongoreschi di matte metafore" (SCT, VII: 7). Sobre los defectos detectados por el preceptista aragonés en el teatro áureo, véase el cap. XV de su libro III de la Poética (1974: 537-546). Sobre la crítica al drama calderoniano en el XVIII, véase Urzainqui (1983: 1493-1512 y 1984).

${ }^{8}$ El italiano aduce no haber encontrado otros ejemplos, refutando las aseveraciones del jesuita Xavier Llampillas, quien había puesto en discusión tal primacía: "L'abbate Llampillas travedendo o volendo far travedere citò una sognata Storia teatrale delle antiche nazioni e della spagnuola da Agustín de Roxas. Essa altra cosa non era -aduce Signorelli- che certi dialoghi intitolati Viage entretenido, dove si trattava del mestiere de della vita laboriosissima de' commedianti Spagnuoli. Può di ciò vedersi Nicolás Antonio, ed il mio Discorso critico"; SCT, VII: 132, nota a.

${ }^{9} \mathrm{Si}$ las piezas de Calderón en la Italia del XVIII obtienen cierto éxito, sobre todo gracias a la adaptación de muchas de sus piezas para el teatro musical (Metastasio y Gozzi fundamentalmente), en España Andioc ha
} 
especial se detiene en la presencia y la popularidad de la que aún gozaba el teatro calderoniano en la Italia del período, citando algunas adaptaciones y traducciones al italiano. Así, por ejemplo, al aludir sobre la amplia recepción del drama áureo en el reino de Nápoles, donde -anota Signorelli en sus Vicenda delle Coltura- hacia finales del XVI "s'introdussero sul gusto del teatro spagnuolo favole romanzesche miste di tragico e di comico e piene di ratti, di duelli, di avvenimenti notturni" (1811, V: 530-1), advierte que las piezas de Calderón aún seguían representándose en los escenarios italianos del setecientos, de modo especial en los coliseos de su ciudad natal, siendo no pocas las piezas del célebre comediógrafo que habían sido traducidas libremente para su representación en los teatros de la península.

Aunque en sus comentarios es posible localizar muchas ideas dominantes propias de la crítica del período, siendo en tal sentido evidente su rechazo al modelo teatral áureo, en estas páginas es posible percibir de todos modos un esfuerzo -parcialmente logrado- por trazar una aproximación más equilibrada y menos apasionada al teatro calderoniano, despojada de prejuicios y alejada de las enconadas polémicas que la obra del célebre comediógrafo había suscitado en aquellos años. Como es notorio, Calderón fue objeto de una amplia crítica a lo largo de la centuria (Urzainqui 1983 y 1984). Los partidarios del neoclasicismo -más allá de matices- impugnaron los ejemplos perniciosos presentes en sus obras y que en su visión alentaban la corrupción de las costumbres y por tanto se revelaban antieducativos desde el punto de vista de la moral. Uno de los autores más implacables en esta perspectiva fue Nicolás Moratín, para quien el teatro debía desempeñar especialmente un rol educador y de formación cívica, consciente de que, como tuvo ocasión de enfatizar en sus Desengaños, "después del púlpito" no había "escuela para enseñarnos más a propósito que el teatro" (1763: I, 12). De ahí la vehemencia de sus ataques contra el autor de La vida es sueño (especialmente contra sus autos), insistiendo sobre todo en la falta de instrucción moral que sus piezas exhibían. Siguiendo las huellas del poeta madrileño, aunque trazando una posición de mayor crédito y apertura hacia el teatro del gran comediógrafo áureo, no son pocas las objeciones que Signorelli enumera, a saber la inobservancia de las reglas clásicas, la presencia de varias situaciones y expresiones extravagantes, la introducción en las tablas de modelos alejados de la naturaleza, numerosos errores de historia, de geografía y mitología, todas ellas ideas dominantes en la crítica ilustrada de aquellos decenios (SCT VII: 52-3). Pero la falta más importante, en su opinión, es la inmoralidad y la falta de decoro que él divisa en sus piezas, acusando al dramaturgo de haber revestido de virtud las debilidades de los hombres, al "hermosear los vicios" ${ }^{\prime 10}$. Este último aspecto para el napolitano constituye un 'error inexcusable', en razón

\footnotetext{
demostrado, en cambio, que, a medida que avanza el siglo, sobre todo en su segunda mitad, a Calderón, como a gran parte de los grandes autores áureos, cada vez se le representa menos y sus obras no logran permanecer muchos días en cartel (1988: 15-23).

${ }^{10}$ Conviene no olvidar lo que al respecto había observado Nasarre, quien, entre otras acusaciones que movió a Calderón, había declarado que "el artificio y afeite con que hermosea los vicios es capaz sin duda de corromper los corazones de la juventud" (en S. de León 2000: 82; subrayado mío). Al aproximarse a los dramaturgos auriseculares, Signorelli refuta en varios pasajes del texto las afirmaciones que Nasarre había vertido en su Disertación (1749). Sin embargo, aunque lo ataque en reiteradas ocasiones o a veces se proponga incluso ignorarlo, en otros, como el recién citado, el hispanista sigue o repite casi textualmente algunas de las apreciaciones del aragonés. Existe ed. moderna del texto de Nasarre: Disertación o Prólogo sobre las comedias de España [1749], ed. J. Cañas Murillo, Cáceres: Universidad de Extremadura, 1992.
} 
del efecto pernicioso que ello podía producir en la juventud, al ofrecer modelos de comportamiento poco virtuosos, como el que exhibían comedias como Galán sin dama (SCT, VII: 52-3) y Empeños en seis horas (SCT, VII: 86-7). Es evidente que en el autor napolitano las cuestiones atinentes a la moral, sobre todo a la moral social, ocupan un lugar tan importante como las concernientes al arte y a las reglas de la poética.

Desde su mirador clasicista y reformador, al apartarse de las reglas de verosimilitud y del buen decoro, Calderón había plasmado en sus comedias temas faltos de moral, como por ejemplo la reprobable influencia de los astros (La vida es sueño y El Tetrarca de Jerusalén), transmitiendo modelos y valores poco virtuosos. Sin embargo, opina que en algunas de sus piezas, de modo especial en sus comedias de capa y espada, es posible reconocer una mayor regularidad y un notable esfuerzo por adecuarse al respeto de la unidad de tiempo (Quinziano, 2005: en prensa). No se olvide que la crítica dieciochesca fue "unánime a la hora de alabar el ingenio dramático de nuestros escritores antiguos, su maestría para trabar multitud de episodios en una acción única y para mantener en vilo el interés del espectador durante toda la representación" (Sánchez de León 2000: 19). Y es que, por lo que respecta a Calderón, como nos aclara Andioc, "la indignación que pueden experimentar los neoclásicos al leer o ver representar una comedia calderoniana, no excluye el respeto al poeta, pues nadie le niega sus eminentes dotes de escritor" (1988: 125). Por lo tanto, nada más alejado de una visión que por decenios intentó instalarse como lugar común, y en la que los defensores del neoclasicismo habrían trazado una visión sistemática y denigratoria del teatro áureo y especialmente del drama calderoniano, fruto de una lectura que no pondera los matices existentes ni los verdaderos propósitos que guiaron a los partidarios de la nueva estética y del rol que ellos asignaron a las comedias auriseculares en su afán de reforma de los escenarios. Según esta concepción, como observa Urzainqui, todo juicio favorable o elogioso al teatro de Calderón en el XVIII fue considerado "como abandono de posiciones neoclásicas o, en todo caso, como desviaciones y rupturas" (1983: 1495) de un sendero que se prefiguraba lineal y claramente adverso al gran dramaturgo áureo. Es verdad que la crítica de matriz clasicista le achacó no pocos defectos y errores, muchos de ellos, como se ha apuntado, evocados también por Napoli-Signorelli (SCT, VII: $52-3)^{11}$, pero no es menos cierto que, como advierte una vez más Andioc, nunca al gran comediógrafo se le confunde "con los Añorbes, Moncines o Zavalas, oponiéndose por el contrario su genio a la medianía de estos últimos" (1988: 125). Y es que en muchas ocasiones se ha pasado por alto que la crítica clasicista del XVIII es fundamentalmente una crítica 'normativa', puesto que se halla orientada a delimitar aciertos y errores en los textos en busca de modelos de imitación; una crítica que, como se ha observado de modo atinado, "aspira, a la vez que a valorar justamente una obra, a servir a la causa de la reforma dramática, enseñando qué es lo que se debe y lo que no se debe imitar" (Urzainqui 1983: 1497). Como mero muestrario de esta parcial valoración, basta recordar que Luzán percibe en el popular dramaturgo a un hombre de portentoso talento, con una gran habilidad para la construcción de estructuras dramáticas capaces de mantener "dulcemente suspenso al auditorio" (1974: 538). Clavijo, quien traza un cuadro despiadado de los autos

\footnotetext{
${ }^{11}$ A este respecto véase el artículo de I. Urzainqui (1983: 1493-1500) de la crítica referida al setecientos (150011), calibrando adecuadamente los errores y los lugares comunes que, y su versión ampliada (1984), donde se incluyen numerosos ejemplos. La investigadora traza un pertinente cuadro por decenios desvirtuaron el sentido de la crítica neoclásica a Calderón.
} 
calderonianos, no puede negar que el escritor se halla dotado de "una gran invención" y presenta "mucha pureza en el lenguaje y una facilidad de versificación que pocos han igualado" (en S. de León 2000: 118-9). En esta misma línea, que insiste en las virtudes del modelo calderoniano, el literato partenopeo pone en evidencia los aciertos del gran dramaturgo. En su opinión, además de poseer una imaginación fecunda (SCT, VII: 53$)^{12}$, el afamado comediógrafo

"non cedeva allo stesso Lope nell'armonia della versificazione; maneggiò la lingua con somma grazia, dolcezza, facilità ed eleganza; seppe chiamar l'attenzione degli spettatori con una serie di evenimenti inaspettati che producono continuamente situazioni popolari e vivaci" (SCT, VII: 53)

Siguiendo el juicio de Luzán, para quien Calderón "sirve y sirvió de modelo" (1974: 404), Napoli Signorelli pone el énfasis en el lenguaje ameno y en la nobleza de la locución, como así también en el acierto en la construcción y solución del enredo, logrando de este modo mantener el interés del espectador 'a través de situaciones vivaces y eficaces'. Su gran ingenio y su virtuosismo al trazar los enredos de las fábulas lo hacían acreedor de alta estima y consideración entre los autores áureos; virtudes que no lograban percibir ciertos "fríos censores" del dramaturgo ${ }^{13}$, por lo que -concluía el italiano en modo polémico- las invectivas que le lanzaban sus enemigos eran inmerecidas y en cierto modo arbitrarias. Napoli Signorelli rechazaba el descrédito al que Nasarre había expuesto ambos dramaturgos, Lope y Calderón, de modo especial este último. A tal propósito PérezVillamil ha precisado con razón que "es curioso el constatar que un extranjero, italiano neoclásico, intuye la verdadera vena y calidad dramática española y arremete contra este español [Nasarre] con visos de erudición" (1980: 113), resaltando la "serenidad del italiano para justipreciar los claroscuros calderonianos" (1980: 115). Interesantes al mismo tiempo son las razones que el italiano alega y que habrían determinado una lectura interpretativa equivocada de la obra calderoniana. En este sentido alude a los errores de interpretación que algunos críticos habían cometido al aproximarse a la obra del célebre dramaturgo, advirtiendo que para juzgar y comprender el valor de un autor es necesario "saper trasportarsi al di lui secolo" (SCT, VII: 54). Por tanto, nos dice el hispanista con juicio, la producción calderoniana debe enmarcarse en el contexto histórico-cultural en que ésta fue concebida y no ser valorada o enjuiciada a partir de las costumbres o de las ideas vigentes o dominantes de un determinado momento histórico, aflorando de modo evidente la vena "historicista" que recorre gran parte de su obra, deudora de la concepción viquiana del desarrollo histórico de los pueblos y las naciones.

\footnotetext{
12. Es común encontrar en la crítica dieciochesca alusión a este aspecto: en este sentido, por ejemplo, Napoli Signorelli lamenta que grandes talentos se hayan abandonado "al trasporto di una immaginazione calda e disordinata, ed innamorati di un parlar gergone metaforico enimmatico gigantesco (...)"; (SCT, VII: 121).

${ }^{13}$ Clara alusión a Blas Nasarre, quien en su Disertación a las comedias y entremeses cervantinos había declarado que "el artificio y afeite con que [Calderón] hermosea los vicios es capaz sin duda de corromper los corazones de la juventud” (en Sánchez de León 2000: 82), atribuyéndole por tanto al gran comediógrafo una gran cuota de responsabilidad por el decadente estado en que se hallaba sumido el teatro en la península.
} 


\section{3. "MALGRADO DELLE BUFFONERIE": LA CRÍTICA A LAS TRAGEDIAS CALDERONIANAS}

Del teatro calderoniano el hispanista italiano se ocupó de modo extenso, dividiendo su dilatada producción en tres parcelas bien delimitadas (SCT, VII: 51-87): los autos sacramentales, y -a semejanza de la división que había trazado precedentemente Luzán ${ }^{14}$ las comedias de capa y espada y las piezas vinculadas al género serio, incluidas en el más genérico apartado por él llamado de las 'favole istoriche' (tragedias, dramas históricos y mitológicos). Es un hecho conocido por todos que los autos fueron uno de los blancos predilectos de la crítica neoclásica que percibió en ellos una manifestación evidente de la decadencia que se había apoderado de los escenarios nacionales. El ataque, empero, como se ha observado con razón, no constituyó un ataque "contra el género como tal, sino contra una concepción y una técnica particulares que, en una época determinada aseguraron el éxito, aparatoso, de ese género" (Andioc 1988: 369). A partir de la crisis de 1648, pero de modo más acusado tras su regreso a Madrid tres lustros más tarde, después de su estancia toledana, Calderón va a detentar casi de modo exclusivo la composición de estas breves piezas de carácter sacro, en las que destacan la portentosa escenografía y la convergencia y suma de toda las artes, desde la música pasando por la deslumbrante disposición visual de tramoyas y apariencias y bailes, expresión significativa de lo que se conoció como la 'gran fiesta barroca'. Sin embargo, los neoclásicos tan sólo percibieron en los autos calderonianos la falta de instrucción moral, el uso impropio y el abuso de las alegorías, la inverosimilitud $\mathrm{y}$, de modo especial, la peligrosa combinación de sacro y profano que dichas piezas exhibían, cuyas arbitrarias interpretaciones podían fomentar comportamientos lindantes con la blasfemia y la herejía y por tanto producir un nefasto influjo sobre la mentalidad religiosa. La crítica neoclásica no percibió la profundidad ni la riqueza teológica y poética presentes en estas piezas de carácter sacro, y como neoclásico, Napoli Signorelli no fue una excepción, enjuiciándolas negativamente. Sus comentarios ocupan apenas algo más de tres páginas $^{15}$, y en esta ocasión, a diferencia de las otras parcelas del drama calderoniano analizadas en su historia teatral, sus comentarios no proceden de un conocimiento directo del género, sino de lecturas y de conversaciones mantenidas con sus amigos madrileños, opositores declarados del género en cuestión.

En sus breves páginas dedicadas a los autos de Calderón (SCT, VII: 54-57), resulta más que evidente el influjo de Nicolás Moratín, "poeta non volgare e scrittore elegante", de quien el crítico italiano evoca precisamente su firme empeño por vencer "il preguidizio dei suoi compatrioti intorno agli auto sacramentali" (SCT, VII: 55, nota a), abogando por su prohibición de los escenarios peninsulares. A tal punto sigue las huellas del autor de La petimetra, que llega a transcribir prácticamente casi los mismos ejemplos (inverosimilitud, errores de historia y geografía, anacronismos, alegorías, etc.) y citar los mismos textos (Laberinto del mundo y Las órdenes militares) ya precedentemente explotados por su

\footnotetext{
${ }^{14}$ En la Poética Luzán divide las comedias de Calderón en tres clases: de teatro, con una maquinaria y escenografía portentosas; las heroicas, en los que "los asuntos y los interlocutores son de alta clase" y las de capa y espada (1974: 404).

${ }^{15}$ El crítico partenopeo ya se había ocupado de los autos, examinando sus orígenes, al aludir a la obra de Lope en el precedente volumen de su Storia critica, VI: 192-6. En dicha ocasión el italiano observa con tino que, así como dichas festividades solían mostrarse en un principio sin recitación alguna "i segni allusivi al mistero, per le strade, per le quali passava la processione, così per le medesime strade prevalse il costume di render parlanti quei segni, e di recitarsi durante l'ottava del Corpus (SCT, VI: 196).
} 
amigo madrileño en sus Desengaños, quien a su vez recordaba haberlas evocado "de pura memoria y sin método ni orden" (N. Moratín 1763, I: 18). La sorprendente coincidencia de los casos referidos revelan el escaso conocimiento directo que el napolitano poseía de estas breves piezas de carácter sacro, algo por lo demás natural, ya que debe recordarse que el italiano había llegado a Madrid algunos meses después que los autos fuesen prohibidos por orden real, confiando por lo tanto en estas apenas algo más de dos páginas en la autoridad (y memoria) de su entrañable amigo español.

Mucho más importantes que su breve y poco novedoso análisis de los autos son por el contrario las amplias páginas que el hispanista italiano dedicó a los dramas históricos, en los que resalta el tono trágico (agrupados por él bajo el nombre de favole istoriche), y aludiendo con ello a las obras de tema épico en la que se exhiben los conflictos y los elementos patéticos de "los mejores hombres" de los que hablaba Aristóteles, y a las comedias de capa y espada, género este último, que a los ojos de los neoclásicos aparecía como mucho más regular y por tanto, ofrecía mayores posibilidades de adaptación a los escenarios del XVIII, previas modificaciones y obligados arreglos. Ahora bien, a la crítica de las comedias de capa y espada, hemos dedicado recientemente un estudio ${ }^{16}$, por lo que en esta ocasión nuestra atención se halla centrada en la crítica que Napoli Signorelli trazó sobre las así llamadas 'fábulas históricas', en las que empero, más allá de alguna rápida alusión a contados dramas históricos y mitológicos, el napolitano acaba ciñéndose a aquellas piezas que gran parte de la crítica ha concebido como pertenecientes al género de la tragedia, asignándoles un indiscutible carácter catársico y trágico.

La preceptiva neoclásica delimitó claramente tanto los ámbitos como los componentes de los dos principales géneros, la comedia y la tragedia, oponiéndose a la combinación de ambas modalidades en una misma pieza y, por lo tanto, rechazando cualquier tipo de modelo que aunara lo trágico y lo cómico, de modo especial la fórmula que había popularizado el teatro áureo, definida por el literato partenopeo como "mescolanze di eroi (...) di buffoni [e ...] atrocità" (EP: 42). Como manifestación de este esfuerzo por delimitar claramente ambas formas teatrales, Luzán había concibido la tragedia como "una representación dramática de una gran mudanza de fortuna acaecida a reyes, príncipes y personajes de gran calidad y dignidad, cuyas caídas, muertes, desgracias y peligros despierten terror y compasión en los ánimos del auditorio y los curen y purguen de estas y otras pasiones" (1974: 433). La definición aquí una vez más pone de realce su función educadora y ejemplar, orientada a provocar en los espectadores "terror y compasión", como prevención frente al dominio de las pasiones humanas. Al aludir a la concepción grecolatina, Signorelli recordaba que Aristóteles, separándose de Platón, había considerado que la tragedia "per mezzo della misericordia e dello spavento, purga, discaccia dal cuore degli uomini tutto ciò che tali passioni hanno di debolezza e di viltà" (EP: 48-49). Siguiendo las huellas del preceptista aragonés, Signorelli establece una similar distinción. Partiendo él también de los planteos de Aristóteles (Poética, parte III), el napolitano concibe la tragedia como

\footnotetext{
${ }^{16}$ La crítica y el comentario que Napoli Signorelli bosquejó sobre las comedias de capas y espada quedan pues exentos del presente estudio; para esta importante parcela del ingente corpus calderoniano, véase nuestro reciente trabajo: Quinziano 2005, en prensa.
} 
imitazione rappresentativa fatta con metro, di azione grande compiuta di personaggi eroici, propria colle sue vicende ad eccitar terror e pietà, per purgar gli animi dello sregolamento di sifatte passioni (EP: 48-49).

Es harto sabido que no existía una larga ni una consolidada tradición del género en los teatros de la península, por lo que la tragedia constituyó una fórmula dramática poco transitada en la tradición teatral hispánica del período, mientras que, por lo que atañe a los neoclásicos, como género la prefirieron a la comedia, por lo que fueron más exigentes con las normas y los preceptos que debían regirla. Ahora bien, aunque Signorelli no compuso tragedias, sí prestó particular atención al género serio. En su Historia crítica de los teatros le dedicó numerosas páginas, con especial atención a la tragedia italiana, francesa y española. Asimismo volvió a ocuparse del tema en Sopra varie tragedie di Agamennone (Venecia: Tipog. Pepoliana, 1791), en la que se abocó al estudio de la tragedia clásica, aspectos sobre los que volvió a insistir en sus traducciones de obras griegas y francesas, publicadas entre 1804 y 1805 , precedidas por un amplio estudio comparativo ${ }^{17}$. Del mismo modo, en esos mismos años traducía del francés para la prestigiosa colección del Teatro Moderno .Applaudito, L'orfano della China, de Voltaire (Venecia: A. Rosa, 1804), autor que el napolitano admiraba y que en numerosas ocasiones elogió en sus escritos de crítica teatral.

En el cuadro de la concepción clasicista del género trágico, Signorelli alabó y apoyó los esfuerzos orientados a poner en escena tragedias según las reglas del arte y siguiendo como ejemplo los modelos que precedentemente habían trazado los antiguos y los clásicos franceses, de modo especial Racine, Corneille y Voltaire. En este sentido, el hispanista italiano evoca los primeros -y de ningún modo desdeñables- tentativos en dicha dirección, a partir de los tempranos experimentos de Montiano y Luyando, cuyas dos tragedias Virginia y Ataúlfo destacan por la "regolarità, decenza, purezza di locuzione e scelta giudiziosa del verso endecasillabo sciolto all'italiana" (SCT, IX: 57). Del mismo modo reivindicará y exaltará los sucesivos intentos que llevan a cabo a partir de la segunda mitad de la centuria sus amigos Cadalso (Sancho García), López de Ayala (Numancia destruida) y Nicolás Moratín (Lucrecia, Hormesinda y Guzmán, el bueno), si bien no escatimó a ellos observaciones críticas, moviéndoles no pocas objeciones, siempre en tono amistoso, como se desprende de las amplias páginas que a sus obras les dedicó en su Historia crítica (SCT, IX: 61-94). Como es bien sabido, estos primeros experimentos se hallan enmarcados en una reforma teatral más general que emprende el conde de Aranda, orientada a proporcionar al teatro español modelos trágicos basados en temas épicos nacionales y según los principios de estricta observancia neoclásica, con la cual el italiano se solidarizó desde sus inicios.

Conviene no olvidar que Napoli Signorelli no concibió estas piezas de Calderón, de estructura compleja y centrados en el indiscutible caudal conceptual y en su profunda carga filosófica, como pertenecientes al género de la tragedia, puesto que para él los modelos ejemplares del género apoyaban en coordenadas estéticas e ideológicas ampliamente alejadas de las que le ofrecía el teatro aurisecular. Ahora bien, sin dejar de reconocer el tono trágico que las permea y la importancia de la vertiente trágica en el drama

\footnotetext{
${ }^{17}$ Delle migliori tragedie greche e francesi. Traduzioni ed analisi comparative di Pietro Napoli Signorelli, Milán: Stamperi e Fonderia al Genio, 1804-05, 3 vols. Cfr. C. G. Mininni (1914: 181-5).
} 
calderoniano $^{18}$, lo cierto es que el mismo Calderón nunca concibió tampoco estos dramas como tragedias, advirtiendo recientemente Froldi que "sólo en tiempos relativamente recientes se ha definido como tal al conjunto de algunas obras que en parte pueden justificar tal definición genérica" (2003b: 321). Un sentido estricto del género, sobre la base de la preceptiva aristotélica y neoaristotélica, excluiría probablemente algunas de estas piezas del horizonte del género trágico ${ }^{19}$. A este respecto, Arellano confirma en cambio la pertenencia de dichas piezas a las leyes del género. En la misma línea de Ruiz Ramón (1984) y Parker (1976), el distinguido hispanista observa que la fatalidad y la cadena trágica de eventos, así como la destrucción del héroe trágico en condiciones de provocar la compasión y el temor del lector y del público, confirmarían por el contrario su plena correspondencia a las leyes del género (2001: 25-6). No es éste el lugar ni mucho menos nuestro propósito ahora adentrarnos en estas páginas en tan compleja discusión. Para nuestro objeto de estudio sólo nos basta precisar, como se ha apuntado arriba, que Napoli Signorelli no concibió estas piezas como adscribibles al género trágico, si bien hoy son muy pocos los que se atreverían a poner en duda la naturaleza trágica de los tres textos - $E l$ Tetrarca de Jerusalén, La niña de Gómez Arias y La hija del aire- ${ }^{20}$ sobre los que el hispanista napolitano hilvanó sus comentarios para referirse a esta relevante parcela del teatro de Calderón.

Es innegable que la mezcla de lo cómico y lo trágico y la presencia de personajes de baja condición social o cuyos perfiles no se hallaban plenamente caracterizados o en su visión ofrecían cierta ambigüedad, como el Octaviano de las escenas finales de El Tetrarca de Jerusalén, junto a situaciones lindantes con lo bufonesco, no cuajaban en su modelo de tragedia, desaprobándolos como impropios del género serio, puesto que rebajaban el aspecto patético de la pieza y la condición noble de los personajes "ilustres y grandes" a los que aludía Luzán (1974: 388), como modelos ejemplares de hombres probos que debían inspirar pasión y piedad en el público. No se olvide por otro lado que los juicios emitidos en el XVIII sobre varias de estas piezas pertenecientes al género serio, o con trasfondo trágico, como fue el caso de ambas partes de La hija del aire, pueden hallarse condicionados en función de la puesta en escena elegida, sobre todo en razón de los destacados montajes escénicos y los efectismos teatrales -visuales y auditivos- que la pieza exhibe, ofreciendo, a través de un portentoso esfuerzo de la maquinaria, de la tramoya y del decorado, la misma espectacularidad a la que estaban acostumbrados los aficionados

\footnotetext{
${ }^{18}$ Para ello remitimos a las oportunas páginas que Arellano dedica a la vertiente trágica calderoniana (2001: 8187).

${ }^{19}$ Recientemente, entre otros estudiosos, A. De Toro ha negado a los dramas de honor calderonianos su pertenencia al género de la tragedia. Según él "el conflicto del honor no se dio en España dentro de la tragedia, al contrario de Italia, sino en particular en la tragicomedia, con la excepción de La desdichada Estefanía de Lope de Vega" (2002: 1), aclarando que se han deformado "los términos aristotélicos y neoaristotélicos en forma arbitraria sin reconocer ni la trayectoria histórico-poético de estos términos ni su trayectoria en la práctica del teatro" al intentar la crítica de modo empecinado "en crear lo que no había: tragedias en España" (2002: 2).

${ }^{20}$ Por el contrario, Froldi recientemente ha puesto en duda que La hija del aire pueda ser considerada una tragedia: en su opinión "no hay en Semímaris un desarrollo interior trágico, pues sustancialmente sufre un destino que aparece determinado", concluyendo que "tal vez se ha dado el error inicial de confundir la riqueza conceptual y la profundidad filosófica de Calderón con lo trágico" (2003a:321). En su opinión, la pieza en cambio representa el preludio del teatro mitológico calderoniano (2003b: 157).
} 
cuando asistían a una "comedia de teatro", como por ejemplo a una comedia de magia o de santos.

Los neoclásicos fustigaron los dramas históricos y las tragedias del gran comediógrafo madrileño, e insistieron en la inobservancia de las reglas de las unidades y en los desarreglos y las extravagancias que para ellos dichas piezas exhibían. Así, por ejemplo, el crítico italiano refuta la inverosimilitud y la presencia del elemento fantástico y alegórico presente en Aurora en Copacavana (llega a dudar incluso que la obra, en su opinión disparatada y 'tutta fantastica', pueda deberse a la pluma del famoso dramaturgo), los aspectos extravagantes que recorren Las armas de la hermosura, ambientada en la Roma antigua, o los numerosos lances que se agolpan en Fineza contra fineza, aludiendo a "evenimenti disparati ed apparenze senza numero" (SCT, VII: 58). Al mismo tiempo, en una clara manifestación del nacionalismo cultural que guía muchas de sus consideraciones, el crítico italiano no pierde ocasión para recordar la primacía de la cultura italiana sobre la hispánica, al observar que en la última pieza recientemente mencionada el autor español "stravolge il bellissimo episodio de Olinto y Sofronio del gran Torquato [Tasso]" (SCT, VII: 58). Pero en este apartado dedicado a las tragedias, como veremos, Napoli Signorelli insiste principalmente en el aspecto moral, censurando algunos modelos humanos y determinados valores que dichos textos exhiben, por él concebidos como ejemplos de teatro antieducativo, puesto que no ofrecen instrucción ni utilidad alguna a los espectadores, enlazando al mismo tiempo, como muchos neoclásicos, el debate moral con el estético.

En el marco del criterio selectivo por él adoptado ("io ne ho scelti ed esaminati i migliori [drammi]"; SCT, VII: 133), el napolitano escruta esta parcela relevante del corpus calderoniano, centrándose en tres piezas que, a pesar de que ofrecen ciertos aspectos reprobables, como la presencia de elementos bufos ("malgrado delle buffonerie", anota Signorelli; SCT, VII: 59), no pertinentes a la seriedad del género, y las no pocas irregularidades que en ellas percibe, destacan sobre las demás por su parcial sobriedad, por sus virtudes líricas y sobre todo por el interés que despiertan (SCT, VII: 59). Nos referimos, como se ha apuntado antes, a tres textos claves del universo trágico de Calderón, a saber $L a$ hija del aire, El Tetrarca de Jerusalén y La niña de Gómez Arias. Ahora bien, si es verdad que la mención de estas piezas, de modo especial las dos primeras, por la calidad artística, la perfección estructural y la profundidad filosófica que exhiben, revelan cierta juiciosa elección, atestiguando además un conocimiento directo de las mismas, como lector y espectador, sorprenden en cambio en estas páginas la escueta alusión a una obra como La vida es sueño, impugnada sin mayores argumentos que la presencia del elemento fantástico y 'el influjo de los astros' (SCT, VII: 68), y algunas llamativas ausencias, como Los cabellos de Absalón, La cisma de Ingalaterra o El sitio de Breda, por mencionar tan sólo tres textos significativos de esta relevante parcela calderoniana a los que no alude. 


\subsection{LA HIJA DEL AIRE}

En La hija del aire ${ }^{21}$, sin duda una de las piezas más conseguidas, redactada muy probablemente entre principios de la década de 1640 y el año de su prepresentación,1653, Calderón retoma el famoso tema de la legendaria reina Semíramis, que había tenido amplia difusión en los textos clásicos, desde la Antigüedad hasta el Renacimiento. Cabe recordar que la historia de la reina asiria había sido llevado a las tablas, entre otros, por el italiano Muzio Manfredi (Semiramis, 1583) y el valenciano Cristóbal Virúes (La gran Semíramis, escrita en torno a 1580 , pero publicada en 1609$)^{22}$. Parece ser que también Lope había redactado una pieza inspirada en el famoso personaje femenino, aunque el texto en cuestión lamentablemente se ha extraviado. Como recuerda Froldi, el literato napolitano exaltó en su Historia crítica de los teatros la versión de Manfredi como perfecto modelo teatral, al concebirla como una tragedia con una sustentable y armónica estructura dramática, la cual, "per uguaglianza, nobiltà e grandezza di stile e per versificazione vince quasi tutte le tragedie del Cinquecento" (cit. en Froldi 200: 114). Respecto a esta pieza como posible fuente de la versión calderoniana, el distinguido dieciochista observa que "es casi seguro que Calderón no conoció esta tragedia italiana, como también considero que Manfredi difícilmente pudo conocer la obra de Virués" (Froldi 2003b: 151). Mucho más factible en cambio nos parece que el dramaturgo español se acercase a la historia de la reina asiria a través de las fuentes medievales y renacentistas y que además hubiese leído la tragedia de Virués, mientras que es de suponer también que conociese la Semíramis de Lope de Vega, aunque al haberse perdido esta última, como observa Froldi, no es posible trazar una comparación entre ambos textos (2003b: 151) ${ }^{23}$.

No fueron pocos los cambios operados por Calderón al redactar su versión de la leyenda, aunque mantuvo las empresas bélicas de la reina, recalcando el perfil negativo de la protagonista basado en su desenfrenada e irracional ansia de ambición y poder, de los que a su vez será víctima. Calderón nos transmite un acabado modelo humano que revela un retrato, perfectamente logrado, de la vanidad, la arrogancia y la crueldad vinculados a los ámbitos del poder y la opresión. Es precisamente el acierto en la pintura de caracteres de la protagonista, Semíramis -ambiciosa, orgullosa, cruel, arrogante, presuntuosa y altiva- el aspecto más conseguido en opinión del crítico napolitano, recalcando que "è dipinto vivacemente il carattere di questa regina straordinaria, piena di valore e ambizione" ( $S C T$,

\footnotetext{
${ }^{21}$ Véase la estimable edición de F. Ruiz Ramón (1987). Entre las últimas aportaciones críticas a la tragedia calderoniana, se precisa tan sólo que recientemente la dra. Uxue Baztán ha defendido en la Universidad de Navarra una tesis doctoral dedicada al estudio de sus dos partes y a las representaciones de la obra a lo largo de los siglos XVII y XVIII. No he podido aún acceder a dicho estudio, que verá la luz próximamente en la prestigiosa Biblioteca Áurea Hispánica, dentro de la colección de ediciones críticas de las comedias de Calderón; agradezco al colega y amigo Alberto Rodríguez, de dicha Universidad, el haberme dado gentilmente noticia de ella.

${ }^{22}$ Para un estudio comparado entre ambas tragedias, la italiana y española, véase el interesante artículo de R. Froldi (2001: 114-25). El destacado hispanista ha publicado también recientemente un trabajo, siempre en clave comparada, sobre las versiones de Virués y Calderón (2003a: 315-24)

${ }^{23}$ Sobre las posible fuente del texto calderoniano, Froldi sostiene además que "es probable que Calderón tuviese conocimiento de la comedia de Vélez de Guevara La corte del demonio, en la cual aparecen los personajes de Nino, de Semíramis (que no es aquí mujer de Nino sino su hermana), de la corrupta Corte de Nínive, pero con una trama de comedia nueva", aclarando empero que "en realidad, de esta comedia Calderón no tomó ningún motivo" (2003: 151).
} 
VII: 59-60). El éxito de la pieza calderoniana a lo largo del setecientos en los escenarios madrileños es sorprendente. La Cartelera teatral de Coulon y Andioc registra para la centuria (1709-1800) unas 40 representaciones, de sus dos partes, en los teatros de Madrid. La vigencia del texto calderoniano tal vez se deba a la puesta en escena como 'comedia de teatro', cargada de espectacularidad y acorde a los gustos del público. Andioc a este respecto recuerda que ambas partes de La hija del aire, por sus características y la sucesión de lances ofrecían un espectáculo similar al de las comedias populares del XVIII, basadas en una importante puesta en escena. El crítico francés recuerda que allí se exhiben "peripecias espectaculares, batallas al son de caja y clarín, reina destronada por el pueblo, evasiones, disfraces" (198: 123), lo que naturalmente encarecía el precio de la entrada, debido precisamente a la maquinaria y a los decorados imponentes escogidos.

Más recientemente, Froldi ha vuelto a insistir en la complejidad de la maquinaria escenográfica que ofrece la pieza, con trompetas y clarines, variaciones en el vestuario, etc.; aspectos, todos ellos, orientados a la búsqueda constante de la admiratio en los espectadores (2003b: 157) y tan acorde a los gustos del público del setecientos (2003a: 322). En los dieciocho años que duró la estancia del napolitano en Madrid, desde setiembre de 1765 hasta finales de 1783, la pieza, en sus ambas partes, revela sin duda una discreta popularidad. Junto con El mayor monstruo del mundo, la obra constituye una de las pocas piezas de Calderón que llegó a gozar de cierta consideración durante la segunda mitad de la centuria (Andioc 1988: 19), habiendo sido representada en dicho período en bien diez ocasiones (Andioc-Coulon 1996, I) ${ }^{24}$. No es muy difícil imaginar, pues, que el napolitano, asiduo frecuentador de los coliseos de la ciudad, haya asistido a varias de estas representaciones durante aquellos años. En dichas ocasiones, como se ha apuntado arriba, es posible reconocer una puesta de escena espectacular y una maquinaria rutilante, sobre todo por lo que respecta a su segunda parte, donde, como nos advierte el mismo Signorelli, la sucesión de eventos son mucho más "dilettevoli e più atti a tirar l'attenzione dell'auditorio" (SCT, VII: 60). Esta acentuación escenográfica no debió convencerle y ello sin duda acabó incidiendo no precisamente de modo favorable en el enjuiciamiento que de la tragedia el crítico italiano dejó estampadas en estas páginas.

\subsection{LA NIÑA DE GÓMEZ ARIAS}

Mucho mayor es el espacio que el crítico napolitano dedica a las dos restantes tragedias, en las que resaltan varias consideraciones estimables referidas a algunas de las situaciones

\footnotetext{
${ }^{24}$ La importante Cartelera madrileña de Andioc y Coulon recoge las siguientes representaciones de la tragedia en el período indicado (setiembre de 1765-1783): Primera parte: 27-29 de mayo de 1766, Teatro del Príncipe; 26-27 de enero de 1767, Teatro de la Cruz; 14-15 de octubre de 1767, Teatro del Príncipe; 12-13 de abril de 1769, Teatro de la Cruz; 25-26 de julio de 1770, Teatro de la Cruz; 12-15 de diciembre de 1774, Teatro de la Cruz; 16-20 de enero de 1777, Teatro de la Cruz; 9-13 de octubre de 1782, Teatro del Príncipe; 6-7 de febrero de 1783, Teatro del Príncipe. Segunda parte: 30-31 de mayo de 1766, Teatro del Príncipe; 28-29 de enero de 1767, Teatro de la Cruz; 16-18 de octubre de 1767, Teatro del Príncipe; 14-16 de abril de 1769, Teatro de la Cruz; 27 de julio de 1770, Teatro de la Cruz; 16-21 de diciembre de 1774, Teatro de la Cruz;21-26 de enero de 1777, Teatro de la Cruz; 1420 de octubre de 1782, Teatro del Príncipe; 8-10 de febrero de 1783, Teatro del Príncipe. Cada una de las partes de la tragedia calderoniana ofrece un promedio de dos o tres días en cartel, con un incremento notable durante los años setenta y principios de los ochenta (1774: 4 días para la primera parte y 6 para la segunda; 1777: 5 días la primera y 6 la segunda; en 1782, la primera parte se mantuvo en cartelera también 5 días, mientras que la segunda parte llegó a permanecer incluso una semana en cartel).
} 
que las vertebran. La niña de Gómez Arias gozó de cierta consideración a lo largo de la segunda mitad del setecientos, reconociendo una importante presencia en los escenarios de la centuria. Según observa Andioc, ciertos elementos constructivos de esta pieza, del mismo modo que Los cabellos de Absalón y el Monstruo de los jardines, debió haberla hecha más atractiva al público del dieciocho, gozando de cierta popularidad, sobre todo en la segunda mitad del siglo (1988: 24-5). Gómez Arias, ejemplo de "espadachín y conquistador de corazones" (Andioc 1988:124), "soldato discolo colpevole di più delitti" nos dice Napoli Signorelli (SCT, VII: 70), constituye para los neoclásicos un modelo claramente condenable, indecoroso e impensable como protagonista de un drama serio. Al igual que en otras ocasiones, el crítico italiano localiza en la pieza la presencia de numerosas expresiones falsas e inverosímiles, como así también algunas inconsistencias dramáticas que, a su juicio, menoscababan la obra (SCT, VII: 70-1). Napoli Signorelli vuelca su interés también hacia cuestiones de estilo y de modo especial hacia las posibles fuentes que habrían inspirado la tragedia calderoniana (SCT, VII: 79), al tiempo que da cuenta además de un buen conocimiento de la historia y de las costumbres españolas, fruto de una adecuada asimilación de lecturas diversas y de sus experiencias viajeras durante sus casi veinte años de estancia en la península ibérica. Así, por ejemplo, al aludir al argumento de la pieza, recuerda que en los montes de las Alpujarras, donde se hallan ambientadas varias de las escenas de la obra de Calderón, una vez reconquistada Granada, "si permise che dimorassero alcuni morii tributari, i quali di tempo in tempo calavano al piano e rendevano schiavi i passeggieri" (SCT, VII: 70).

Ahora bien, sin subestimar estas aportaciones, lo más interesante de estas páginas referidas a La niña de Gómez Arias es la libre traducción italiana de la escena III de la útima jornada $^{25}$ que el napolitano efectúa con el declarado propósito de ofrecer al lector un ejemplo de depuración lingüística acorde a sus presupuestos estéticos, tal vez pensando en una futura adaptación y representación de la pieza en los escenarios italianos (SCT, VII: 728). Ya en otra ocasión, al referirnos a sus versiones de las comedias de Leandro Moratín, hemos aludido a las virtudes del hispanista italiano como traductor de textos españoles y a su perfecto dominio de la lengua de Cervantes, como para detenernos ahora en este aspecto. Tan sólo nos permitimos aquí recordar que el autor de la Storia critica, una autoridad en aquellos años por lo que respecta al teatro hispánico y experto conocedor de la lengua española, traduce con pericia lingüística las comedias del autor de El Sí de las niñas, manipulando en algunos casos con cierta libertad los elementos y los procedimientos teatrales con el propósito de adaptarlos a la escena italiana y a las procupaciones y gustos del público de la península (Quinziano 2001: 270-287) ${ }^{26}$. No se olvide por otro lado que el crítico napolitano, no sólo se cimentó en la traducción de textos españoles, volcando al italiano cuatro de las cinco comedias moratinianas (y viceversa, del italiano al castellano, una larga carta de tema científico $)^{27}$, sino que además adaptó y tradujo al italiano tanto

\footnotetext{
${ }^{25}$ A este respecto, el crítico italiano, al referirse a este pasaje, explicando su elección, declara que "meritano di notarsi la querele di Dorotea, malgrado de' freddi concetti che la deturpano" (SCT, VII: 71).

${ }^{26}$ Sobre las traducciones al italiano de las comedias moratinianas, además de mi citado artículo (2001: 270-87), remito a dos trabajos claves: Mariutti de Sánchez Rivero (1960: 763-805) y Caldera (1980:149-160).

${ }^{27}$ Véase la Lettera del Conte Saluzzo al barone Giuseppe Vernazza sulla trasformazione dell'acido vitriolico in acido nitroso; tradotta in castigliano, Impressa in Madrid [1783], en Opuscoli Vari, II, Nápoles, Orsino, 1793, pp. 153-165. [La primera ed., Traducción castellana de una Carta del Conde de Saluzzo sobre la transformación del
} 
tragedias griegas como francesas, algunas de ellas estudiadas incluso en una apreciable perspectiva comparada, como en las ya aludidas Delle migliori tragedie greche e francesi (1804-5). En dicho esfuerzo destacan el análisis y las traducciones del Hipólito de Eurípides y la Fedra de Racine, que ocupan el primer volumen de la obra, y el análisis y la traducción de la Ifigenia in Aulide de Eurípides con la homónima de Racine. En todas ellas nuestro autor revela su habilidad como traductor y su gran conocimiento no sólo del español, sino también del francés y de las lenguas clásicas, idiomas que cultivó con fluidez y que dominó con sabiduría filológica.

Por lo que respecta a la libre traducción al italiano de algunos pasajes de la pieza calderoniana, centrada todos ellos en el dramático diálogo de Dorotea que ocupan la tercera escena de la última jornada, ambientada en las proximidades de la ciudad de Benamexí, es interesante observar que Napoli Signorelli hace partícipe al lector de su estrategia traductora y le informa claramente que en esta labor de poda y de lima textual eludirá la traducción de los versos en los que "i tratti patetici vengono traditi dalle false espressioni" (SCT, VII: 72), transcribiéndolos luego, aunque parcialmente, a pie de página. Alude con ello a los vocablos por él considerados artificiales y pomposos y a las expresiones y fórmulas rebuscadas en las que se percibe la acumulación de símiles, metáforas y conceptos que él define 'incoherentes' y que menoscababan el principio de verosimilitud, aspecto que, como neoclásico, en su opinión toda pieza teatral debía exhibir. Y para que el lector italiano -a quien no olvidemos iba dirigido prevalentemente su historia teatral- pueda cotejar las diferencias y los contrastes, producto de su selección estética, opta por transcribir en pie de página algunos pasajes o ciertas expresiones del texto original que, por las razones antes aludidas, prefiere no traducir al italiano. Así, por ejemplo, cuando, se refiere al momento acusadamente dramático en que Dorotea impreca contra su amante, quien, después de haberla abandonada y haberla ultrajada en más ocasiones, ha decidido venderla a los moros, el napolitano decide traducir solamente los epítetos del primer verso que abren la queja de la protagonista femenina:

Mostro, barbaro, ingrato, ove trascorri?

(...)

(SCT, VII: 72)

mientras que elude los siguientes versos, para explicar a pie de página las razones que le han llevado a eliminarlos en su traducción parcial. Al respecto anota que "l'originale è più abbondante (...) ma mi è sembrato estremamente ricercato ed incoerente il cumulo di simili e vi si profondono affettatamente" (SCT, VII: 72, nota a), transcribiendo a continuación, aunque de modo parcial, el pasaje omitido ${ }^{28}$.

ácido vitriólico en nitroso, con advertencias del traductor Signorelli, publicada en Madrid en 1783, nunca ha sido localizada]. Cfr. al respecto Minnini (1913: 83-84 ) y sobre todo Cian (1896: 178-180), quien se refiere al vivo interés que el napolitano manifestó por las ciencias experimentales.

${ }^{28}$ Transcribimos aquí el texto que hace referencia a los pasajes iniciales de la querella de Dorotea y que, a excepción del primer verso, el italiano opta por no traducir a causa del amontonamiento de adjetivaciones y de símiles 'extremadamente rebuscados': "Monstruo, ingrato, bruto fiero,/ pasmo horrible, asombro vil,/ fiera inculta, aspid traidor,/ cruel tigre, ladrón nebli,/ león herido, lobo hambriento, / horror mortal, y hombre en fin,/ por decirte de una vez/ cuanto te puedo decir,/ ¿Qué intentas, qué solicitas,/ qué determinas, que así/ en tu ofensa todo el cielo/ conjuras, sin advertir/ que a tanto delito ya/ todo su imperial zafir/ piadosamente irritado,/ forjando 
Del mismo modo, al evocar los últimos versos de la misma escena, cargados de fuertes tonos histriónicos, Napoli Signorelli establece una amplia depuración de gran parte de los vocablos allí invocados y que en la versión del italiano, en función de su finalidad 'purificadora' orientada a eliminar los períodos largos, redundantes y rebuscados, acaban sintetizados en los dos opuestos cielo/tierra, concebidos por él como síntesis de la variada enumeración de imágenes y conceptos del que hace alarde el texto calderoniano

\section{P. Napoli Signorelli}

Signor, mio bene,

Pietà di me, pietá di te; rientra

In te stesso per te; cangi il pentirti

In merito il delitto; o tu vedrai

Congiurato in tuo danno e cielo

e terra (a)

Signor, pietà, mercè,

Non mi lasciare, oimè!

Presa in Benamexì,

In man del Cagnerì.

(SCT, VII: 78; las negritas son mías)

\section{Calderón de la Barca}

$\mathrm{Ea}$, señor, dueño mio

Mi cielo y mi bien, en ti

Vuelve por ti mismo, y sea

El mirarte arrepentir

Mérito ya, y no delito;

Porque de no hacerlo así,

Cielo, sol, luna y estrellas,

Sin alumbrar ni lucir;

Hombres, aves, fieras, peces,

Sin obrar ni discurrir,

Montes, peñas, troncos, fieras,

Sin albergar ni servir;

Agua, fuego, tierra y viento,

Sin animar ni asistir,

Atentos a acción tan fea,

Se volverán contra ti,

Viendo que de tantas veces

No te enternece el oir

Señor Gómez Arias,

Duélete de mí,

No me dejes presa

En Benamejí.

(Tercera Jornada, III: 39; las cursivas y negritas son mías)

El literato italiano vuelve a defender el criterio selectivo adoptado en su estrategia traductora, argumentando que una vez más ha optado por la economía narrativa y la síntesis descriptiva. Declara en este sentido que ha preferido traducir en un solo verso "un finale istrionico, solito a porsi nelle relaciones" (SCT, VII: 78, nota a), recordando que en el texto original Dorotea le dice a su amante "che si volgeranno contro di lui cielo, sol, luna, estrellas, hombres, aves, fieras, peces, montes, peñas, troncos, brutos, agua, fuego, tierra, viento", (SCT, VII: 78, nota a), enumerando de este modo las imágenes por él omitidas. Según el napolitano, la amplia enumeración del texto original, distribuida en grupos de a cuatro en el marco de estructuras paralelísticas, constituye una redundante acumulación de conceptos, aunque es evidente que la labor y la elección del traductor en este caso no tiene en cuenta la riqueza y la variedad conceptual que ostenta la tragedia calderoniana. En otras 
ocasiones las omisiones hacen referencia a expresiones o a pasajes completos que, en su opinión, atentaban o eran contrarios "al vero e alla passione", (SCT, VII: 76): En todos estos casos el italiano establece un criterio de selección sobre claros presupuestos estéticos e ideológicos, pensando en una posible reutilización de textos áureos en los escenarios del setecientos y ejemplificando dicho proceso de adaptación desde su mirador clasicista.

La selección lingüística y estética que opera el hispanista italiano no hace más que confirmar la varias veces declarada voluntad de depuración que caracteriza a los neoclásicos en su propósito de purificar el teatro barroco, suprimiendo conceptos, vocablos y expresiones que atentaban contra los principios del decoro y la verosimilitud, ya sea porque "contrario al vero e alla passione" (SCT, VII: 78, nota a), ya sea a causa de un estilo concebido como excesivamente rebuscado y basado en la acumulación de símiles y metáforas, aspectos que en su opinión conferían a la pieza visos de incoherencia y de inverosimilitud dramáticas. Estas páginas, pues, pueden ser entendidas en el marco del declarado propósito que guía a los preceptistas del dieciocho en su intención de amoldar algunas piezas del teatro áureo a los cánones clasicistas, convencidos de que, arregladas según dichos principios, dichas obras serían más perfectas artísticamente y al mismo tiempo mayormente aplaudidas por el público. En estas páginas referidas a La niña de Gómez Arias, que configuran un interesante intento de purificación lingüística del teatro barroco y una invitación a la reutilización de sus textos más significativos y de mayor valor artístico, el crítico partenopeo establece un posible itinerario de selección lingüística, consciente de la necesidad de aprovechar la fecunda imaginación y la riqueza de motivos y de caracteres que ofrece la vena dramática calderoniana para que, una vez traducidos y depurados según los principios fijados por el neoclasicismo, algunas de sus obras pudiesen ser representadas y fuesen mayormente aceptadas en los escenarios italianos del período ${ }^{29}$.

\subsection{El Tetrarca de Jerusalén o El Mayor monstiruo del MUNDO}

Como es sabido, El Tetrarca de Jerusalén (conocida también como El mayor monstruo del mundo, en la que sustantivo "monstruo" alude a la fuerza de los celos), escenifica la historia de Herodes y su mujer Mariene. De esta obra, sin duda uno de los dramas calderonianos más logrados, "de gran calidad y fuerza trágicas", según palabras de Ruiz Ramón (2000: 247), y cuya representación, como confiesa el mismo napolitano, más veces había tenido ocasión de presenciar durante sus casi cuatro lustros en Madrid (SCT, VII: 60), Napoli Signorelli resalta principalmente el trazado de los caracteres de los dos personajes primordiales. Así exalta la grandeza de Mariene, "virtuosa quanto bella", personaje que remite al modelo ejemplar, mientras que Herodes, "eccesivamente amante e geloso" (SCT, VII: 60), alude al modelo negativo, ejemplo de mal gobernante y modelo de príncipe irracional, prisionero de unos celos patológicos por Mariene que se convertirán en el motor del desenlace trágico que acabarán provocando su propia caída y destrucción ${ }^{30}$.

\footnotetext{
${ }^{29}$ Sobre la presencia del teatro calderoniano en la Italia del XVIII, véase Pepe (1955) y Durán y González Echevarría (1976, I: 65-6).

30 Sobre el perfil y el desarrollo de los caracteres de ambos personajes remito al interesante estudio de Arellano (1999: 137-147), quien de modo acertado anota que el juicio sobre Herodes no puede desligarse del ideal de príncipe que caracteriza la España del XVII (1999:143), y cuyos perfiles se hallaban presentes principalmente en los tratados de Saavedra Fajardo (Idea de un príncipe político cristiano) y Solórzano Pereira (Emblemas regiopolíticos).
} 
Su descripción de la trama, basada en el trío temático tirano-celos-honor, es por momentos excesivamente minuciosa, quebrando de este modo en algunos pasajes la vivacidad y agilidad de la prosa. No cabe duda alguna de que el escritor napolitano conocía perfectamente la trama y las diversas escenas que organizan la tragedia, ya que, como acaba de apuntarse, él mismo se encarga de precisar que el texto constituye una de las piezas teatrales que más veces había tenido ocasión de presenciar durante su estancia en Madrid. Ahora bien, aunque es evidente que el italiano puede hacer gala de un conocimiento directo de la obra en cuestión - como lector y espectador- y más allá de su exaltación en el trazado de los caracteres de Mariane y Herodes, a diferencia del precedente análisis de La hija del aire, no distingue las virtudes dramáticas que exhibe la pieza, desconociendo la perfección en su estructura y su eficacia y consistencia teatrales que -como ha observado Arellanoapoyan en un acabado desarrollo de la gradación climática y de la técnica de la premonición (2001: 85 $)^{31}$. No cabe duda de que su percepción del género, a diferencia de lo que le ofrecían los dramas de honor de la Italia del XVI y XVII, en los que resalta de modo evidente la vertiente trágica, se halla alejada del modelo que le ofrece la pieza de Calderón, la cual, en su opinión, no puede ser inscripta en el género serio, a causa "delle buffonerie che ho tralasciate, dell'irregolarità e delle avventure comiche notturne" (SCT, VII: 67). En un reciente estudio en clave comparada, A. Toro niega "a los dramas de honor en España no así en Italia (...)- el título de tragedias, porque faltan los elementos de la acción "hamartía'/"anagnórisis" ( 2002: 5). En su opinión "el tema del honor no es trágico en sí, pero sí lo puede ser su tratamiento" (2002: 5) y apunta que "el conflicto del honor no se dio en España dentro de la tragedia, al contrario de Italia, sino en particular en la tragicomedia, con la excepción de La desdichada Estefanía de Lope de Vega" $(2002: 1)^{32}$, constituyendo en dicho sentido La Marianna de Dolce (1555?) y la pieza de Calderón, ambas centradas en el tema de Herodes y Mariane, dos claros ejemplos de estas divergencias en cuanto al planteo del tema del honor y al respeto de la tipología del género trágico por parte de la tradición teatral en ambas penínsulas. Ahora bien, más allá de estas diferencias en el trazado de los temas de honor en los escenarios áureos de Italia y España, se ha observado con razón que El mayor monstruo del mundo es tal vez una de las piezas calderonianas más

\footnotetext{
${ }^{31}$ Para las virtudes de la pieza calderoniana, véase el recién citado e iluminante estudio de Arellano (1999: 124161).

${ }^{32}$ A este respecto De Toro opina que "las situaciones finales acostumbradas de los dramas de honor españoles no son trágicas en lo fundamental porque, vistas las cosas desde la perspectiva del personaje principal, el vengador, no hay nada o apenas algo que lamentar, y para ello es indiferente que se mate a la mujer como inocente o como culpable. En la mayoría de los dramas de honor que conocemos, sobre todo en los de final infeliz, falta en una medida considerable una tematización, una problematización y una interiorización del conflicto de honor en el texto interno, explícitas y suficientemente amplias. Ese conflicto no conduce a un análisis interno del código de honor, no se reflexiona sobre ello, sino que se actúa mecánicamente, como si fueran personajes con una conciencia limitada, o bien unilateralmente dirigida" (De Toro, 2002: 6). El autor, pues, excluye a los dramas de honor auriseculares dentro de la denominación genérico-tipológica de 'tragedia'; lo que no significa, aclara a renglón seguido, "que en los mismos esté totalmente excluido lo trágico" (2002: 6). Entre los elementos trágicos que De Toro percibe en dichos dramas, por él vinculados al género de la tragicomedia, se encuentran "la desesperación que sienten los personajes de cara al peligro de perder el honor", "el mantenimiento en secreto de la deshonra supuesta o de hecho, así como que los personajes afectados no verbalicen su situación", "el aislamiento, la soledad en que caen el o los deshonrados, presuntamente o de hecho, como consecuencia del silencio", "la pérdida de la vida -sobre todo en el caso de mujeres inocentes- y la mancha que, pese a la venganza consumada, queda en la honra de algunos personajes femeninos".
} 
complejas y difíciles de apreciar para un lector o espectador alejado de las convenciones estéticas y de los códigos ideológicos en la que ésta fue concebida (Ruano de la Haza 1989: 10). En dicha perspectiva la crítica neoclásica, en la que se inscribe el comentario del literato napolitano, constituye un claro y temprano ejemplo de esta dificultad y de la evidente dislocación en la percepción de las obra del teatro áureo. En este sentido Arellano recuerda un comentario publicado en el Memorial literario, en el que se alude al "estilo pomposo" de la obra y a los "enormes yerros que cometió Calderón en las grandísimas quiebras de lugar, y crasa ignorancia de la geografía", para rematar que "si un monstruo deja de tener alguna regularidad, se puede decir que esta tragicomedia es tan monstruosa como el mismo título" (cit. en Arellano 1999: 126-7). Como advierte una vez más Arellano, "algunas opiniones que sobre esta tragedia calderoniana se han expresado desde el siglo XVIII hasta nuestros días prueban esta dificultad y sobre todo muestran la influencia que tiene en la interpretación de la pieza la adopción de un sistema de convenciones impertinente"(1999: 126), alejado de su preciso marco de referencia, tanto estético como ideológico. No asombra, pues, si el literato partenopeo enumera en estas páginas una larga lista de defectos que constituyen un muestrario bien representativo de las impugnaciones que al drama aurisecular avanzaban los neoclásicos, censurando en primer lugar la finalidad antieducativa de la pieza, colocándola fuera del sistema de valores ético-moral que propugnan los ilustrados. Entre las principales objeciones que Signorelli establece destacan la ausencia de las reglas de las unidades (centrada especialmente en los 'saltos' espaciales: "da Gerusalemme a Menfi e da Menfi a Gerusalemme"; SCT, VII: 68), la presencia de lenguaje pomposo y del abuso de juegos de palabras, las redundancias en la explicación de algunas situaciones, bregando por una mayor economía lírica, la existencia de numerosas expresiones fantásticas y situaciones inverosímiles y extravagantes ${ }^{33}$, la combinación de elementos bufos y cómicos mezclados con las situaciones trágicas e impropias del género, los pensamientos patéticos combinados con "impertinencias pedantescas", la presencia perniciosa del elemento sobrenatural (como el influjo de los astros) en el desarrollo de los eventos, y sobre todo la falta de decoro, como le revelan algunas escenas en las que interviene el "poco grave" Octaviano, y cuya aventura nocturna de la escena final, para el italiano, lo aproxima más al modelo de las comedias de capa y espada que a la gravedad que debía exhibir un personaje tan distinguido y elevado (SCT, VII: 60-68). Al referirse a Mariene, el literato italiano valora el tono y la fuerza dramática de sus quejas (sus 'querele'), que concibe como 'apropiadas' y 'patéticas'34, aunque, del mismo modo que en sus comentarios sobre la Dorotea de La niña de Gómez Arias, no por ello deja de observar que sus querellas y lamentos se hallan confundidos "in un mucchio d'espressioni fantastiche" o "sono frammaschiati a varie impertinenze pedantesche di quel tempo" (SCT, VII: 64 y 65).

\footnotetext{
${ }^{33}$ Así por ejemplo, en el marco de su afán depurador, señala que de los 75 versos que componen el diálogo en que Tolomeo, apuñalado en el hombro, se dirige a Herodes (I, escena 4), él suprimiría, al menos, 60 de ellos: "un poeta più sobrio -anota Signorelli- avrebbe ad un moribondo risparmiato almeno sessanta di questi versi ed un paio di dozzine di pensieri stravaganti" (SCT, VII: 61).

${ }^{34}$ Signorelli alude de modo especial al diálogo en que Mariene intercede ante Octaviano para que salve a Herodes, perdonándole la vida: “¿para que gobiernas si no escuchas?” (SCT, VII: 64), destacando la 'grandeza’ y 'vivacidad' del personaje femenino.
} 
Sin embargo, en el implacable enjuiciamiento que develan estas páginas, el autor partenopeo insiste principalmente en las situaciones inverosímiles que pueblan la pieza calderoniana, entre las que recuerda la presentación de Jerusalén como ciudad marítima, la voluntad de Herodes en convertirse emperador de Roma y la escena en que la caída 'fortuita' del retrato de Mariene se interpone al puñal de Herodes, salvando así de segura muerte a Octaviano ${ }^{35}$, sin olvidar la serie de casualidades que modelan la escena final y que para él ofrecen claros visos de inverosimilitud. Su comentario de la tragedia es, pues, decididamente negativo. Percibe tantas irregularidades en la obra, que llega a poner en discusión incluso su misma pertenencia al género serio, sobre todo debido a las bufonadas y a las aventuras cómicas nocturnas (advirtiendo la presencia de aspectos y recursos propios de las comedias de capa y espada en la presentación de algunas situaciones y de determinados personajes, de modo especial el Octaviano de la visita nocturna a la habitación de Mariene). Napoli Signorelli refuta las elecciones operadas por el célebre dramaturgo en el desenlace de la pieza, donde el comportamiento de Herodes y Octaviano y la situación de la escena final, "contesa tutta comica ed indecente" (SCT, VII: 66), constituyen una clara violación de los principios de verosimilitud y del decoro al que en cambio dichos personajes, desde su mirador clasicista, por su nobleza y status, debían atenerse.

No es azaroso suponer por otro lado que estos juicios de valor sean no sólo la natural derivación de su conocida adhesión a los principios neoclásicos, sino que sobre ellos estén actuando, aún más directamente, los modelos teatrales italianos que se habían ocupado también del tema de Mariene y Herodes y que el dramaturgo napolitano conocía perfectamente, de modo especial la tragedia renacentista de Ludovico Dolce, La Marianna, de mediados del XVI, y la libre versión de la pieza calderoniana adaptada por el florentino Giacinto Andrea Cicognini, publicada en 1656 con el título de Marianne ovvero Il maggior mostro del mondo y mencionada en la célebre Drammaturgia de L. Allaci (Venecia: G. Pasquali, 1755) ${ }^{36}$. En dicha perspectiva, el crítico teatral se adentra también en cuestiones de fuentes y examina, en clave comparada, los posibles modelos que habrían inspirado el drama de Calderón. Polemizando con el abate Andrés, uno de los principales mediadores culturales entre ambas penínsulas hespéricas, Signorelli considera que es la versión italiana de Ludovico Dolce, "tragedia regolare" y sin duda una de las más destacadas del Renacimiento italiano, recitada con éxito en el palacio ducal de Ferrara (SCT, VII: 69), y no la de Calderón, la que habría servido de fuente y modelo a la historia de Mariene y Herodes redactada por Tristán, subrayando la distancia abismal que mediaba entre la versión neoclásica del dramaturgo francés y la del comediógrafo madrileño "in cui si vedono tinte comiche miste alle tragiche [e] tante irregolarità" (SCT, VII:68). Aunque el autor de la Storia critica polemiza injustamente varias veces con el célebre erudito alicantino, y en más ocasiones, como ejemplo evidente de su nacionalismo cultural, insiste en la defensa y la

\footnotetext{
${ }^{35}$ Sobre la posible inspiración o influencia de este situación, Lida de Makiel recuerda que "el cuadro que cae providencialmente se halla también en La prudencia en la mujer impresa en la Parte tercera de las comedias de Tirso, (Tortosa, 1634) y, al parecer, anterior al drama de Calderón" (1977: 79-80, nota 29).

${ }^{36}$ Sobre la libre adaptación de Cicognini, Durán y González Echevarría han observado que, respecto a la tragedia calderoniana, el italiano "simplifica el estilo y abandona el verso por la prosa; acelera la acción a costa de hacerla inverosímil (1976: 65).
} 
supremacía del teatro italiano sobre el hispánico, es difícil en este caso no darle razón, ya que no son pocas las diferencias reconocibles entre la tragedia gala y la del gran dramaturgo español. En verdad no sólo por la mayor 'regularidad' a la que alude Napoli Signorelli, sino por varios otros motivos, empezando por las fuentes utilizadas, que emparentan la versión renacentista del italiano y la neoclásica de Tristán. No se olvide que el tema desarrollado por Dolce tiene su punto de partida en las Antigüedades judaicas (I, XV, Cap. 3, 8, 9) de Flavio Josefo (Basilea 1544), y reconoce una importante presencia entre mediados del XVI y la primera de la centuria siguiente, ya que volvemos a encontrarlo nuevamente en la Herodiade de Giambattista Martii (1594), y también más tarde en la Alejandra, de Leonardo Argensola, para finalmente recalar en El Mayor monstruo del mundo, de Calderón, a partir del cual luego Giacinto Andrea Cicognini redacta su versión italiana (De Toro, 2002: 13, nota 23). Como recuerda Lida de Makiel, aludiendo a las posibles fuentes utilizadas para las diversas versiones teatrales del tema, las Antigüedades judaicas y la Guerra de los judios, esta última también deudora de la pluma del cronista Flavio Josefo, Calderón "elige también como Tirso, la versión rápida de la Guerra, mientras que los dramaturgos no españoles prefieren la versión detenida de las Antigüedades" (1977: 77-8). La autora nos aclara que Dolce, Hardy y Tristán adoptan como base "la del segundo viaje de Herodes, en que éste la confía a Soemo [y que...] mantienen en toda su importancia el papel de Mariamne", por lo que los autores no españoles, a diferencia de Calderón, "respetan mucho más la verdad histórica del drama"(1977: 78). En la versión calderoniana, por tanto, concluye Lida, "se sustituye la realidad natural y la histórica con la realidad del mito (...): el acierto ineluctable del agüero, la coincidencia matemática del azar" (1977: 79).

No cabe duda de que a Signorelli la versión de Dolce, al igual que la de Tristán, se le presenta naturalmente mucho más regular y más adecuada a los preceptos aristotélicos y neoaristotélicos que habían modelado los elementos constitutivos del género serio ${ }^{37}$, ofreciendo al mismo tiempo un mayor efecto trágico del desenlace de la trama. Respecto a este último aspecto, para el crítico napolitano el tema del amor y del honor en la escena final de la tragedia italiana adquiere mayores dimensiones trágicas y una más amplia tematización respecto al final de la pieza de Calderón:

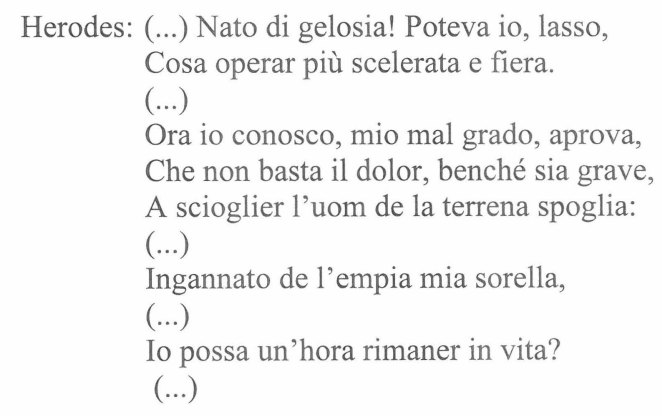

\footnotetext{
${ }^{37}$ Como se ha puesto de relieve, en la obra de Dolce "se adoptan múltiples marcas trágicas presentes hasta entonces en las obras de Eurípides y Séneca, en la Orbecche de Cinthio y la Canace de Speroni; el motivo del honor y de los celos, junto con el del disimulo, el engaño, la astucia y la mentira, es tema central" (De Toro, 2002: 12).
} 


\author{
Ahi Marianna mia piangerò sempre \\ Il grave mio peccato, e la tua morte. \\ (L. Dolce, La Marianna, V: 865; 875-876; cursivas mías)
}

Mientras en el drama de Dolce, al matar Herodes a Mariane, aquél abomina y repudia su accionar, y fruto de su propia reflexión acaba arrepintiéndose, sumiéndose en un profundo pesar reflejado en el luto riguroso que el personaje asume, todos estos elementos se hallan ausentes en el drama español ${ }^{38}$. A diferencia de Dolce, en el Herodes de Calderón no es posible hallar ningún indicio de reflexión, de arrepentimiento o una mínima señal de repudio a su propio comportamiento (aunque sí, para evitar que alguno tome venganza, el personaje optará arrojarse al mar desde una torre); son el destino -el hado- (enjuiciado esto muy negativamente por el crítico italiano) y los celos los reales motores de la trágica muerte de Mariene y así nos lo explica el mismo Herodes en el desenlace:

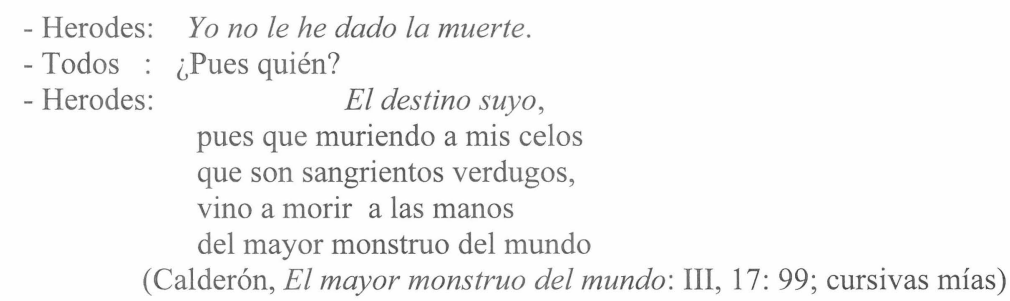

Ahora bien, esta ponderación y primacía de la pieza italiana, que había precedido de casi un siglo la calderoniana, no constituye un obstáculo para que, en otra de sus incursiones en clave comparada, reconozca Signorelli los valores de la pieza española, y así, si la versión italiana y la de Tristán superan la del madrileño en cuanto a regularidad, perfección teatral y dimensiones trágicas, el drama de Calderón ofrece en cambio un tratamiento mucho más vivaz y acabado de los caracteres de Mariane y Herodes, al trazar de modo más logrado ya sea el perfil "sensibile e grande" de aquélla, como la furia celosa e irracional de su marido (SCT, VII: 68-70). En resumen, es evidente que el hispanista italiano, situado en un marco de convenciones estéticas y éticas fuertemente distanciado del ámbito de emisión y recepción de la obra, la España aurisecular, no logra apreciar el mensaje ni la perfección de la estructura dramática de la pieza española, como así tampoco

\footnotetext{
${ }^{38}$ A este respecto, De Toro señala con tino que "el enfrentamiento crítico con el honor, abierto, diferenciado y característico de la tragedia de honor italiana, el sopesar el pro y el contra de la venganza, la mujer que se defiende a sí misma y que desea demostrar su inocencia, la problematización y el cuestionamiento del someter a juicio los propios asuntos, y asimismo las dimensiones del amor y el arrepentimiento aparecen en La Marianna con particular énfasis" (2002: 14), concluyendo el estudioso que "un final con un lamento tan conmovedor y arrepentido como el de Herodes [en la pieza de Dolce] es desconocido por los dramas de honor españoles" (2002: 14). Estos aspectos, en efecto, se hallan ausentes en el drama español de honor; y el mismo Signorelli, al aludir al desenlace de la pieza calderoniana y a la trágica muerte de Mariene, debía pensar en algunos de ellos, concibiendo la importancia asignada por el dramaturgo español a la serie de casualidades y sobre todo al tema del hado ("influsso degli astri", $S C T$, VII: 69), como aspectos que menoscababan la dimensión trágica de la pieza. De todos modos, con Ruiz Ramón (2000: 247) y Parker (1973: 187-8 y 1976), somos de la opinión que en la tragedia española, además del destino, tienen asimismo importancia, en dosis combinadas con el hado, la libertad y la voluntad de cada uno de los personajes, responsables por tanto también de su propia caída. Interesante también la interpretación que traza Arellano, para quien, valorando -además del hado- la responsabilidad de los personajes en el desarrollo de la trama, es posible reconocer otro principio clave, 'la ironía trágica', "mediante la cual cada acción conduce a efectos opuestos a los deseados" (1999: 134).
} 
los elementos trágicos ni la larga cadena de causas y de responsabilidades humanas - de ningún modo mecánicas ni arbitrarias-, las cuales, combinadas con el hado, llevarán a los personajes al cumplimiento de su trágica caída. Por su formación y su adhesión a los principios del clasicismo dieciochesco tampoco se halla el hispanista italiano en condiciones de valorar las virtudes del lenguaje dramático que exhibe la pieza, por él definido en cambio como 'delirii dei seicenteschi' (SCT, VII: 64), ignorando la indiscutible naturaleza declamatoria y esencialmente teatral que permea el texto y que, como manifestación notable del drama áureo, apoya en la expresión aguda de símbolos, imágenes y $\operatorname{conceptos}^{39}$. Siendo un neoclásico convencido, su atención se halla centrada principalmente en la vertiente ético-moral y en el mensaje antieducativo que a su entender la pieza transmite. Para los ilustrados, como es sabido, la representación dramática, sin dejar de ser por ello entretenimiento, debía subordinar principalmente la obra a la transimisión del mensaje, el cual no podía ser ni inmoral ni ambiguo. El autor napolitano insiste en varias ocasiones sobre esta importante función social y didáctica asignada al teatro, uno de los tópicos mayormente presentes en las preceptivas del setecientos, concibiendo la representación dramática como scuola di sana morale (EP: 98) y por tanto como uno de los instrumentos primordiales de 'pública educación'. De ahí que Signorelli refute especialmente la presencia perniciosa de los elementos maravillosos e inverosímiles presentes en este drama de honor, puesto que, nos dice el crítico partenopeo, al igual que en La vida es sueño y en lugar de enseñar que determinados comportamientos, como las desenfrenadas pasiones y los celos, ocasionan la caída y la ruina de sus protagonistas, el madrileño "si è studiato d'insegnare che esse provengono dall'influsso degli astri", no siendo precisamente ello "una bella moralità da insinuarsi dalle scene" (SCT, VII: 68).

\section{CONCLUSIÓN}

Como la mayor parte de los preceptistas neoclásicos, Napoli Signorelli percibió en Calderón virtudes y defectos. En este péndulo, que Cañas Murillo ha definido de "tira y afloje" (1992: 73) ${ }^{40}$, transita la crítica del literato italiano, refutando varios componentes de su fórmula teatral y revalorizando al mismo tiempo otros aspectos de su amplia producción dramática. En dicha perspectiva, el napolitano en más ocasiones, como en la polémica que mantuvo con Nasarre, no dudó en enfrentarse a quienes pusieron en discusión el valor, las virtudes y la misma inspiración artística que habían modelado las piezas de los grandes autores del teatro aurisecular, asumiendo una valiente y equilibrada toma de posición - y aún más por tratarse de un crítico extranjero y por lo demás italiano, en un momento en que abundaban las polémicas estéticas y culturales entre ambas penínsulas hespéricas- y polemizando con quienes ponían en discusión las virtudes y los aciertos de sus mayores exponentes, especialmente Lope y Calderón. Napoli Signorelli, sin desconocer los defectos que desde su mirador clasicista se hallan presentes en las obras calderonianas, exalta la

\footnotetext{
${ }^{39}$ En este sentido Arellano nos recuerda de modo pertinente que "el lenguaje de Calderón es estrictamente dramático, integrado en la acción y en la representación", debido a que "lleva implícitamente en sí mismo la vocación de la actio -o declamación en el escenario-" (1999: 156).

${ }^{40}$ La expresión la utiliza el crítico extremeño en su comentario de la Disertación moratiniana que precede su edición de la comedia La petimetra (1989: 73, nota 75).
} 
vena artística del autor español, percibiendo que sus textos revelan un no sé qué (un 'perché), un espíritu activo, vivaz y encantador; algo, como precisó Urzainqui, "de indefinible belleza, capaz de encantar a los públicos españoles y extranjeros" (1983: 1510). Desde esta perspectiva, las consideraciones del hispanista napolitano, centradas en deslindar las virtudes y los defectos del teatro calderoniano, revelan un valorable esfuerzo por precisar de modo más equilibrado y juicioso y menos apasionado la colocación del célebre comediógrafo, en quien percibe dotes de gran dramaturgo, sobre todo en sus comedias de capa y espada ${ }^{41}$, por supuesto dentro de los marcos y de las concepciones que le consentían su estricta adhesión a los dogmas neoclásicos.

Sin embargo, por lo que atañe al género de la tragedia, la crítica del hispanista italiano es mucho más severa, casi implacable. Al referirse al género trágico, Napoli Signorelli enjuicia de modo positivo el trazado de algunos caracteres (Herodes, Mariene, Dorotea, Semíramis) y valora acertadamente algunos pasajes de El Tetrarca de Jerusalén y La niña de Gómez Arias, "per vari tratti poetici e per situazioni pregievoli" (SCT, VII: 59), de modo especial las 'querele' patéticas de las protagonistas femeninas Mariene y Dorotea. Interesantes se nos revelan al mismo tiempo sus esbozos de libre traducción y de depuración lingüística y estilística de algunos pasajes de La niña de Gómez Arias, encaminados a una posible adaptación y reutilización de piezas áureas en los teatros italianos del XVIII según los cánones clásicistas, al tiempo que sugestivos nos parecen también algunas de sus incursiones en clave comparada, cuando alude a posibles fuentes y a las traducciones y adaptaciones en la Italia del período. Ahora bien, más allá de estas valoraciones, el cuadro que traza Signorelli no es muy alentador, explicando que Calderón "ove per lo più vollendo esser tragico, grande, sublime, diventa turgido, pedantesco, puerile" (SCT, VII: 80). Es que como neoclásico convencido, el crítico italiano olvida las virtudes dramáticas del modelo trágico calderoniano, por lo que es obvio que su mirador sustentado en las reglas del clasicismo dieciochesco se revela impertinente como sistema para enjuiciar adecuadamente y de modo acabado las piezas del autor áureo. El modelo que le ofrecen las tragedias calderonianas, en las que él distingue numerosas irregularidades y un lenguaje pomposo y artificial, se halla ostensiblemente alejado de su concepción del género serio. Para el napolitano el mayor acierto del dramaturgo madrileño radica no en sus tragedias, sino en sus comedias de capa y espada (SCT, VII: 80-87). En este sentido, a diferencia de lo que pensaba Estala, para quien "Calderón tenía un genio más apropiado para la tragedia que para la comedia" (cit. en Checa Beltrán 1990: 29), el hispanista italiano duda de la esencia trágica del gran dramaturgo español y de su predisposición hacia el género serio, mostrándose éste, por el contrario, mucho más orientado hacia el universo cómico teatral, como le revelan sus comedias de capa y espada, en las cuales Signorelli percibe mayor regularidad, situaciones interesantes y un estilo más acorde al género y por tanto mayores niveles de elaboración artística.

\footnotetext{
${ }^{41}$ Ruiz Ramón ha puesto en evidencia la maestría de Calderón en la elaboración de estas piezas cómicas basadas en la capacidad de provocar la admiratio del público a través de situaciones ingeniosas, destacando "la perfección de la mecánica teatral con que construye sus mundos cómicos, donde ni un solo cabo de la intriga queda suelto, ni un solo nudo sin desenlazar" (2000:257). Sobre la crítica y el valor asignado a las comedias calderonianas de capa y espada, me permito remitir una vez más a mi reciente estudio (Quinziano, 2005: en prensa).
} 


\section{REFERENCIAS BIBLIOGRÁFICAS}

ANDIOC, R., Teatro y sociedad en el Madrid del siglo XVIII, Madrid, Castalia, 1988, $2^{\text {a }}$ ed. corregida y aumentada [1976].

ANDIOC, R. y COULLON, M., Cartelera madrileña del siglo XVIII.(1708-1808), 2 vols., Tolosa, Presses Universitaires du Mirrail, 1996.

ARELlANO, I., Convención y recepción. Estudios sobre el teatro del Siglo de Oro, Madrid, Gredos, 1999.

ARELLANO, I., Calderón y su escuela dramática, Madrid, Ediciones del Labirinto, 2001.

BIGI, E., Nota introduttiva a P. Napoli Signorelli, en Dal Muratori al Cesarotti, Milán, Ricciardi, IV, 1960, Vol. 44, pp. 587-643.

CALDERA, E., "Pietro Napoli Signorelli, traduttore di Moratín", en Studi di letteratura italiana in onore di Fausto Montanari, Génova, Il Melangolo, 1980, pp. 149160.

CALDERÓN DE LA BARCA, P., La hija del aire, ed. de F. Ruiz Ramón, Madrid, Cátedra, 1987.

CALDERÓN DE LA BARCA, P., La niña de Gómez Arias, en Comedias de Don P. Calderón de la Barca, ed. J. E. Hartzenbusch, Madrid, Atlas, 1945, IV: 1-43.

CALDERÓN DE LA BARCA, P., El mayor monstruo del mundo. ed. de J. M. Ruano de la Haza, Madrid, Espasa-Calpe,1989.

CIAN, V., Italia e la Spagna nel secolo XVIII. Giovambattista Conti e alcune relazioni letterrarie fra l'Italia e la Spagna nella seconda metà del Settecento, Turín, Lattes, 1896.

CHECA BELTRÁN, J., "Los clásicos en la preceptiva dramática del siglo XVIII", en Cuadernos de Teatro Clásico, 5 (1990): 13-31.

DE TORO, A., "Honor-deseo-sexualidad y estrategias de substitución y de subversión en los dramas españoles e italianos de los siglos XVI y XVII", en Actas del Convegno Tragedie dell'onore bell' Europa barocca. Sezione di italiano dell'Università di Losanna e Centro di studi sul teatro medievale e rinascimentale di Roma (Lausanne:14-16 noviembre de 2002), pp. 1-33. Internet: http://www: uni-leipzig.de/ detoro/sonstiges/Texto.deToro.pdf-

DOLCE, L., La Marianna. Tragedia, en R. Cremante (ed.), La Letteratura Italiana. Storia e Testi. Teatro del Cinquecento. La Tragedie, Milán-Nápoles, Ricciardi, 1988, vol. 28, I, I, pp. 729-877.

DURÁN, M. y GONZÁLEZ ECHEVARRÍA, R., "Introducción", en Calderón y la crítica: historia y antología, Madrid, Gredos, 1976, 2 vols.

FERNÁNDEZ DE MORATÍN, L., Vida de don Nicolás Fernández de Moratín [1821], en Obras de don Nicolás y don Leandro Fernández de Moratín, Madrid, Atlas, BAE:2, 1944, pp. VI-XIX.

FERNÁNDEZ DE MORATÍN, L., Disertación, en La petimetra [1763], ed. de J. Cañas Murillo, Badajoz, Universidad de Extremadura (Textos Unex), 1989. 
FERNÁNDEZ DE MORATÍN, L., Desengaños al teatro español [I-III], Madrid, s.i, 176263,3 vols.

FROLDI, R., "La legendaria Semíramis, protagonista de dos tragedias de finales del Quinientos, compuestas por el italiano M. Manfredi y por el español C. de Virués", en D. Ferro (ed.), Trabajo y ventura. Studi in onore di Carlos Romero Muñoz, Rom, Bulzoni, 2001, pp. 114-125.

FROLDI, R., "La legendaria reina de Asiria, Semíramis, en Virués y Calderón", en Criticón, 87-89 (2003 a): 315-324.

FROLDI, R., "La gran comedia de la Hija del aire", en M. Tietz (ed.), Teatro Calderoniano sobre el tablado. Calderón y su puesta en escena a través de los siglos.(Actas XII Coloquio Amglogermano sobre Calderón; Florencia, 10-14 de julio de 2002), Stuttgart, F. Steiner Verlag, 2003 b, pp. 145-161.

LIDA DE MAKIEl, M. T., Herodes: su persona, reinado y dinastía, Madrid,Castalia, 1977.

LUZÁN, I., Poética [1737], ed. de Rusell P. Sebold, Barcelona, Labor, 1977.

MARIUTTI DE SÁNCHEZ RIVERO, A., "Un ejemplo de intercambio cultural HispanoItaliano en el siglo XVIII: Leandro Fernández de Moratín y Pietro Napoli Signorelli", en Revista de la Universidad de Madrid, IX (1960), pp. 763-808.

MININNI, C.G., Pietro Napoli Signorelli: vita, opere, tempi, amici, Città di Castello, Lapi, 1914.

NAPOLI SIGNORELLI, P., Opuscoli Vari, Nápoles, Stamperia Orsiniana, 1792-95, I-IV vols.

NAPOLI SIGNORELLI, P., Elementi di poesia drammatica, Milán, s.e., 1801. Sigla: EP

NAPOLI SIGNORELLI, P., Vicenda della coltura delle due Sicilie, Nápoles, Orsino, 18101811 [1784-86], 6 vols.

NAPOLI SIGNORELLI, P., Storia critica dei teatri antichi e moderni, Nápoles, Orsino, 1813 [1777], $3^{\text {a }}$ ed., 10 vols. Sigla: SCT

PARKER, A., "Prediction and its dramatic function in El mayor monstruo los celos", en R. O. Jones (ed.), Studies in Spanish Literature of the Golden Age presented to E. M. Wilson, Londres, Támesis, 1973, pp. 173-192.

PARKER, A., "Hacia una definición de la tragedia calderoniana", en N. Durán y R. G. Echevarría (eds.), Calderón y la crítica, Madrid, Gredos, 1976, 2 vols., II, pp. 359-387.

PEPE, I., "Motivi calderoniani nella letteratura settecentesca", en G. Mancini (ed.), Calderon in Italia: studi e ricerche, Pisa, Università, 1955.

QUINZIANO, F., "La commedia nuova" (1795): P. Napoli Signorelli, traduttore e diffusore del teatro 'ilustrado' di L. Fernández de Moratín", en G. Catalano y F. Scotto (eds.), La nascita del concetto moderno di traduzione: le nazioni europee fra enciclopedismo ed epoca romantica, Roma, Armando ed., 2001, pp. 259-287.

QUINZIANO, F., "Pedro Napoli Signorelli y Leandro Fernández de Moratín: amistad, afinidades e influjos literarios", en E-Humanista. Journal of Iberian Studies 
(University of California- Santa Barbara). 2 (2002): 188-236. Internet: http://www.spanport.ucsb.edu/ projects/e-humanistal

QUINZIANO, F., "Caro soggiorno. Pedro Napoli Signorelli en la España del XVIII", en Dieciocho (University of Virginia), 26.2 (2003): 241-264.

QUINZIANO, F., "En torno a Calderón en el siglo XVIII: Pietro Napoli Signorelli y la crítica al teatro calderoniano", en I. Arellano y E. Cancellier (eds.), La dramaturgia de Calderón. Estructuras y mecanismos, Pamplona, GRISOUniversidad de Navarra, 2005 (en prensa).

RODRÍGUEZ SÁNCHEZ DE LEÓN, M $M^{\mathrm{a}} \mathrm{J}$, La crítica ante el teatro barroco español (siglos XVII-XIX). Estudio introductorio, selección y ed. de M. J Rodríguez Sánchez de León, Salamanca, Almar, 2000.

RUIZ RAMÓN, F., Calderón y la tragedia, Madrid, Alhambra, 1984.

RUIZ RAMÓN, F., Historia del teatro español. 1.Desde sus orígenes hasta 1900, Madrid, Cátedra, 2000 [1967], 10ª ed., 2 vols.

SORIANO PÉREZ VILLAMIL, E., España vista por historiográfos y viajeros italianos (1750-1799), Madrid, Narcea, 1980.

URZAINQUI, I, "De nuevo sobre Calderón en la crítica del siglo XVIII”, en L. García Lorenzo (ed.), Calderón. Actas del Congreso Internacional sobre Calderón y el teatro español del Siglo de Oro, Madrid, CSIC, 1983, 3 vols., III, pp. 1493-1512. Ed. ampliada: Oviedo, Universidad/Cát. Feijoo, 1984. 
